\title{
State-Owned Banks in the Market for Corporate Control
}

\author{
Bacchiocchi E., Ferraris M., Florio M., Vandone D.
}

\begin{abstract}
In this paper we analyse the general question of state-owned versus privately owned banks' performance by focussing on a specific segment of the industry: banks that are growing in size acting as acquirers in the market for corporate control. We build up a unique data set of 3,682 deals between banks that allows us to classify M\&As into four categories, depending on the ownership of the acquirer and the target. Econometric analysis highlights that state-owned banks that are playing as acquirers in the M\&A arena perform better than their private benchmark; results are even stronger for development bank.
\end{abstract}

Keywords: State-Owned Banks, Development Banks, Ownership, Market for Corporate Control, Mergers and Acquisitions.

JEL Codes: G32, G34, L32 


\section{Introduction}

Despite the waves of privatizations observed over the last decades, state ownership in the financial sector is still far from insignificant. State-owned banks (SOBs) account for $25 \%$ of the total assets of the banking system around the world; in the European Union, the share rises to $30 \%$, and it is even higher in the BRIC countries, namely Brazil, Russia, India and China (OECD, 2012). In turn, financial companies account for $24 \%$ of the assets of all State-Owned Enterprises (SOEs), and they represent the second-largest industry, after the network industries (Florio,2013), in which government holdings are concentrated (OECD, 2014). SOBs are also growing in size through the Market for Corporate Control (MCC) - that is the arena in which alternative teams compete for the right to manage corporate resources (Jensen and Ruback, 1983) - where they have been acquirers in a relevant number of deals and for significant amount of assets: in the last ten years more than $10 \%$ of M\&A deals have involved state-owned banks as acquirers (Zephyr data) ${ }^{1}$.

Notwithstanding the relevance of these trends, together with rasing concerns on efficiency grounds, little is known on contemporary SOBs. Traditionally, SOBs are said to be less efficient and profitable than privately owned enterprises, as they may have alternative goals, such as social (Gerschenkron, 1962; Atkinson and Stiglitz, 1980; Altman, 1993; Laffont and Tirole, 1993; Stiglitz, 1993) or political purposes (Kornai, 1979; Shleifer and Vishny, 1994; Shleifer and Vishny, 1997; Frydman et al., 1999; La Porta et al., 2002; Carvalho, 2014). However, contemporary SOBs are quite different organizations from the traditional SOBs of the last century. SOBs have been frequently opened to private capital and are ultimately controlled by the State, often by means of minority stakes, competing in a globalized scenario, and facing similar issues and challenges than private banks (Pargendler et al. 2013). Overall, contemporary SOBs have been deeply reformed - changes in corporate governance rules and regulatory framework, higher transparency and accountability, compliance with ethical and deontological requirements - with the aim to strengthen their performance (OECD 2012). The process has been particularly important for development banks, of which 287 entities in 117 countries have been identified (Musacchio and Lazzarini, 2014, p 13).

Those changes call for a fresh look at them, confirmed by a revival of interest in contemporary public companies, especially those operating on a global scale (Karoly and Liao 2015).

In this paper we analyse the firm-level characteristics and operating performance of a specific segment of SOBs: those who are players in the MCC and, therefore, are actively participating to the above mentioned expanding role of governments. Specifically, we analyse Merger and Acquisition (M\&A) deals involving banks during the last decade and we ask whether SOBs that are active in the market for corporate control have pre-deal characteristics that are similar to or different from their private counterparts, i.e. private banks that are active in the same market. Such evidence would indirectly signal some convergence of managerial models and operational mechanisms of state-owned and privately owned banks, at least for a specific segment of the stateowned banks. We also investigate which specificities - if any - are related to the various types of deal in which the acquirer is involved. Given that extant literature cites different reasons for M\&As, from shareholder value maximization to support of troubled institutions (DeYoung et al. 2009), we aim at gaining insight into behaviour of SOBs and the role of government in the

\footnotetext{
${ }^{1}$ These trends are in line with a more general return of State-Owned Enterprises (SOEs) as players in several industries. In the last decade, 2,057 major SOEs have combined equity value of almost $\$ 2$ trillion, more than 6 million employees, operating revenues equal to $19 \%$ of global cross-border sales, and around $6 \%$ of world GNI. Furthermore, since 2008 finacial crisis, the role of SOEs in developed economies has been increasing dramatically: the shares of equity holdings by some OECD governments has increased up to $20 \%$ of their GDP (OECD 2010; OECD 2011). Notably, in 2011 the value of the assets of the targets purchased by SOEs was equal to 433 billion euros, which corresponds to the $17 \%$ of the total assets of the targets that have been traded in the M\&A arena (Zephyr data).
} 
financial market. To the best of our knowledge no previous papers have focused on deals performed by state-owned banks or on the pre-deal characteristics of state-owned acquirers.

Having in mind these questions, in investigating the pre-deal performance of the acquirers, we also account for the different nature of state-owned banks. Indeed, previous literature has always considered state-owned banks as a unique entity, while they are not, and this may well account for differences in the relative performance of state-owned banks versus private banks.

We identify two main types of players -commercial banks and development banks - which may be quite different in terms of mission, business model, type of activity and targeted market segment. In fact, state-owned commercial banks offer a wide variety of banking and financial services targeted to retail as well as corporate customers and covering deposits and accounts, credit cards, loans, stock market services, insurance, asset management, and so on. After 2008, the number of state-owned commercial banks increased because of the nationalization of some large groups, which were severely affected by the global financial crisis. In Europe, between 2008 and 2013, member states granted an overall amount of 448 billion euros in recapitalization measures and other forms of bail-out. The UK, Germany, Ireland and Spain are the countries that supported their banks most, respectively with 100.14 billion, 64.17 billion, 62.78 billion and 61.85 billion. Some examples of the receiving banks from those countries are the Royal Bank of Scotland, Northern Rock, Lloyds Banking Group, Barclays Bank (UK), Hypo Real Estate Bank, Commerzbank, Sparkasse KolnBonn, Nordbank (Germany), Allied Irish Bank, Anglo Irish Bank (Ireland) and Bankia (Spain).2 As a consequence, some of these banks are now ultimately owned by governments.

Development banks are different. They are public sector or government invested entities with an explicit mandate to promote socio-economic goals in a region, sector or specific market segment. Their core activity is to carry out lending operations either directly to end-customers (so-called first-tier development banks) or to other private financial institutions that in turn lend to endcustomers (second-tier development banks) (World Bank, 2013). They can also acquire stakes in the equity of their customers. Development financial institutions are established both in emerging countries and in advanced economies, for example the Business Development Bank of Canada, Finnvera (Finland), Kreditanstalt fuer Wiederaufbau KfW (Germany), KBN Kommunalbanken Norway (Norway), Bank Gospodarstwa Krajowego BGK (Poland), European Bank for Reconstruction and Development EBDR (European Union), European Investment Bank EIB (European Union), Japan Development Bank (Japan) and the recently established Green Investment Bank (UK). In the last few years, development banks have been receiving growing attention given the countercyclical role that they played during the recent global financial crisis by increasing the supply of credit to the private sector while private banks experienced temporary difficulties (World Bank, 2011, 2013; OECD, 2012; Mazzuccato and Penna, 2014). In analysing M\&A deals - half of which performed by development banks - we find interesting differences in the pre-deal characteristics of these two types of banks.

To pursue our aim, a great effort was made to collect data for individual deals performed between 2003 and 2013. We combine information from two databases managed by Bureau Van Dijk: Zephir, on M\&A deals, and Bankscope, on banks' financial statements. The combination of the two data sets allows us to collect accounting and financial features of both the acquirer and the target banks; the identification of the ownership of the banks has been a crucial step. The overall sample includes 3,682 deals that occurred during the period 2003-2013. Matching the two databases has also enabled us to classify M\&As into four categories, depending on the ownership of the acquirer and the target: 1) private reorganization, when a private bank acquires another

${ }^{2}$ For detailed information about aids in the context of the economic and financial crises, see European Commission (2014). 
private bank; 2) privatization, when the target only is a state-owned bank; 3) publicization, when a state-owned bank acquires a privately owned bank; and 4) public sector reorganization: when both the acquirer and the target bank are state-owned. Among the state-owned acquirers, we also identify deals performed by development banks and by state-owned commercial banks by looking at the nature of each state-owned bank in the data set.

We first estimate a set of linear regression models to highlight how the ex-ante performances of the acquiring banks are connected to their ownership. We then explore, using a second set of models, the relationship between the type of deals and the financial characteristics of the dealers.

Our main findings is that, in the decade 2003 to 2013, the segment of state-owned banks that are active in the market for corporate control perform better than their private benchmarks, after controlling for other bank-specific and deal-specific variables. The results are stronger for development banks. A battery of robustness tests confirms our results.

The remainder of the paper is organized as follows. Section 2 discusses the motivation for our research and presents an overview of the earlier literature on banks' M\&As and state-owned banks' performance. Section 3 describes our data set. Section 4 highlights the research methodology, while the main results are presented in Section 5. In Section 6, we finally conclude.

\section{Motivation}

Traditionally, state-owned banks are said to be less efficient and profitable than privately owned banks, either because they pursue social objectives or because they are run by political bureaucrats. According to the first view - also referred to as social view, development view or benign view - government-owned banks contribute to economic development and improve general welfare. This view underlines the role of the public sector in compensating for market imperfections that leave socially valuable investments underfinanced. Indeed, public banks are considered necessary for substituting private intermediation in projects with positive social returns but negative private returns, as well as to direct savings toward strategic long-term projects (Gerschenkron, 1962; Atkinson and Stiglitz, 1980). This role of state ownership in banks is similar to the role of public ownership in other industries but the reasons for such ownership are sharper for financial intermediation, in which the marginal social cost for the economy of systemic risks and bank failures are considered to be more relevant than the failure of other types of business firms (Altman, 1993; Laffont and Tirole, 1993; Stiglitz. 1993). Conversely, according to the more sceptical political view, state-owned banks are inefficient since they are mechanisms for pursuing the individual goals of politicians, such as providing employment, financing favoured enterprises or transferring resources to their supporters and political allies. Indeed, politicians create and maintain state-owned banks to maximize their personal objectives rather than channelling funds to socially efficient uses (Kornai, 1979; Shleifer and Vishny, 1994, 1997; Frydman et al., 1999; La Porta et al., 2002; Bortolotti and Faccio, 2009; Carvalho, 2014, Musacchio and Lazzarini 2014).

However, in the last decade, the empirical evidence from the strand of literature that analyses the issue of the relationship between government ownership and bank performance has been more mixed than before. A body of evidence is in line with the traditional findings and highlights that state-owned banks are inherently less efficient than private ones. Berger et al. (2005), using data from Argentina in the 1990s, find that state-owned banks tend to have poorer performance relative to other banks, particularly very high non-performing loan ratios. Similar findings are reported by Iannotta et al. (2007) using a sample of 181 large banks from 15 European countries over the 1999-2004 period. The authors find that government banks have lower profitability and loan quality and higher insolvency risk than private banks. Chen and Liu (2013) also report that government-owned financial institutions in Taiwan have a return on assets that is lower than that 
of the average private institutions. Jiang et al. (2013), examining the static effect of ownership and the dynamic effect of privatization on bank performances in China over the period 1995-2010, find that the ownership structure matters to bank performance and state-owned banks are associated with lower efficiency. Another body of evidence, however, report different or less clear-cut findings. Cornett et al. (2009) use pooled cross-section and time-series regressions to investigate the effect of state ownership on bank accounting performance in 16 Far Eastern countries from 1989 to 2004. They find that the performance of state-owned banks is inferior to that of privately owned banks; however, the differences reduce over time, probably because of the increasing globalization of financial services competition, which may have the salutary effect of disciplining inefficient regulators and improving the performance of state-owned banks. Micco et al. (2007) analyse the relationship between bank ownership and performance for a sample of banks that ranges from 5,465 in 1995 to 6,677 in 2002, for 179 countries across the world, using standard indicators of bank profitability and efficiency. They find that state-owned banks located in developing countries have much lower returns on assets than their private counterparts; however, those located in industrialized countries are not significantly different from their private counterparts. The latter results are in line with Altunbas and Marques (2008) who, focusing on the German banking system, find little evidence that privately owned banks are more efficient than state-owned banks, while the latter have slight cost and profit advantages. Little difference in stateowned banks' and privately owned banks' performance is also found by Figuera et al. (2009) using cross-sectional data over 20 countries.

In fact, in recent years, there has been a widespread tendency by governments to strengthen the performance of state-owned banks by improving their governance. Poor governance of stateowned banks - due to the presence of a weak board of directors subject to political pressures and to managers lacking professional skills and experience - is considered to be one of the most relevant explanations for the historical poor performance of state-owned enterprises (OECD, 2012). A number of countries, although not all, have undertaken important reforms to empower state-owned banks' boards, to shield them from political intervention and increase their autonomy and to enhance their competence through skill-based nomination processes (OECD, 2005, 2011). Those global changes potentially work in the direction of aligning the operational mechanisms of state-owned and privately owned banks facing similar issues and challenges.

In our paper we analyse the general question of state-owned versus privately owned banks' performance by focussing on a specific segment of the industry, where banks, either state-owned or private ones, are active as acquirers in the M\&A arena, with both domestic and cross-border deals. Our null hypothesis is that the pre-deal characteristics of this more dynamic segment of state-owned is similar to that of private banks.

The empirical literature on the market for corporate control in the banking industry is huge ${ }^{3}$; however, no previous papers have analysed deals according to the ownership of the acquirer.

A subset of studies focus, as we do, on the pre-deal characteristics of targets and acquirers with the aim of shedding light on the firm-specific features of acquirers and on the hazard of being acquired. Among them, Hannan and Pilloff (2009) and Hernando et al. (2009) are the most relevant ones. Hannan and Pilloff (2009) investigate the determinants of interstate and intrastate acquisitions using a competing-risk proportional hazard model, in which the type of acquirer, classified according to location and size, defines the competing risks. Their sample consists of 8117 banks observed over the period 1996-2005 and 1741 acquisitions divided into i) small and in-market, ii) small and out-of-market, iii) large and in-market and iv) large and out-of-market. Profitability is measured by the ROA, and inefficiency is measured by the non-interest expenses divided by the sum of non-interest income and net interest income. They find that less profitable and more inefficient banks are more likely to be acquired, suggesting the existence of potential

${ }^{3}$ See De Young et al. 2009 for a comprehensive literature review of financial institutions M\&As. 
post-merger performance gains. Hernando et al. (2009) estimate through a multinomial logit model the differences between the banks that were targets versus those that were not acquired in the EU-25 over the period 1997-2004. Their sample contains 1342 private banks (in our meaning) and 157 deals, of which 39 were cross-border. They use three proxies for the target's operating performance - the return on average ratio, the cost to income ratio and the net interest margin and find that poorly managed EU-25 banks are more likely to be acquired by other banks.

\section{The data set}

\subsection{Deals and ownership}

Our sample consists of 3,682 M\&A deals performed worldwide by banks over the period 20032013. The data set is obtained by combining two sources of information, Zephyr and Bankscope, ${ }^{4}$ both of which are from Bureau Van Dijk. We first collected the identification numbers of all the banks available in Bankscope from 2003 to 2013 and we then matched these data with Zephyr. We obtained an initial large data set of M\&A deals involving banks over the period 2003-2013; for each acquirer, vendor and target involved in each deal, we then recorded, when available, information about the type, year, country, sectors (NACE Rev.2 code) and ownership (global ultimate owner, GUO). ${ }^{5}$

The identification of the ownership of the bank has been a crucial step in setting our database. This needed to build up a logic algorithm. Information about the firm's GUO provided by Zephyr refers only to the latest available year, rather than to the year when the deal occurred. Hence, when defining the ownership type of any banks involved in the deal, there is the possibility of wrongly considering as state-owned ( respectively privately owned) a bank that is state-owned (privately owned) nowadays but that was not state-owned (privately owned) at the time of the deal. This misreading may happen both on the acquirer and on the target side. To avoid this potential error, we restricted our sample to those observations for which the ultimate owner of both the acquirer and the vendor has not changed since the time of the deal. ${ }^{6}$ With this aim, we developed an algorithm to extract only those observations for which both the vendor and the acquiring company involved in a deal (at time $\mathrm{t}$ ) do not figure as target companies in a subsequent deal (at any time $\mathrm{t}+\mathrm{j})$.

The result of this strict selection procedure is a sample of 3,682 observations (deals). At this stage, we were able to use the information on the banks' current ultimate owner. After identifying the ownership, we finally matched these data with Bankscope to obtain - for each deal - accounting information for the acquirer and for the target involved in each deal.

\footnotetext{
${ }^{4}$ https://www.bvdinfo.com. Zephyr is a data set that contains information about deals, while Bankscope is a database of banks' financial statements. Given our research question, we matched the two data sets.

${ }^{5} \mathrm{We}$ consider as state-owned any bank of which the ultimate owner, defined as the independent shareholder with the highest direct or total percentage of ownership, is a central or local public entity, including public authorities, governments, municipalities and local entities. Further, we consider this independent shareholder to be an ultimate owner (UO) of a bank if it holds more than $25 \%$ of the shares.

${ }^{6}$ To ascertain the pre-deal ownership nature of the target, we look at the ownership type of the vendor, while we look at the acquirer's ownership to infer its post-deal ownership. In the rest of the paper, we thus report information on the ownership of targets and acquirers.
} 
According to the ownership of the acquirer and the target, we identify four types of deals in decreasing order of frequency in our sample:

1) Private reorganization, when a private acquirer deals with a private target;

2) Privatization, when a private acquirer deals with a state-owned target;

3) Publicization, when a state-owned acquirer deals with a private target;

4) Public reorganization, when a state-owned acquirer deals with a state-owned target.

Table 1 shows that $22 \%$ of the deals in our sample involve state-owned banks, either as the acquirer or as the target. As it happens, this share in terms of the number of deals is not far from the share of public banks in the industry (in terms of assets) as estimated by the OECD (2012).

Tables 2 and 3 provide information on the number of deals and banks involved by year, by type of ownership and by geographical distribution. Table 2 compares the data between the pre-global crisis years (2003-2008) and the more recent post-crisis period (2009-2013). M\&As are split into the four above-mentioned categories according to the ownership of the acquirer and the target involved in the deal. In Table 3, deals are split into domestic deals, when both the acquirer and the target are from the same macro-geographic area, and cross-border deals, when the macrogeographic area of the acquirer differs from that of the target. The main relevant trends are: a) the number of deals increases after the 2008 crises (but in part this may reflect the increased coverage by the Zephyr database); b) over $60 \%$ of the deals overall are recorded in Europe (Western and Eastern), but in recent years, Eastern Europe and Central Asia have recorded higher numbers than Western Europe; and c) the large majority of deals are domestic, but a non-negligible $18 \%$ of the deals are cross-border. As regards our main research focus, the sample includes 441 privatizations overall and 367 deals in which a state-owned bank is the acquirer (both of private and of stateowned banks).

\subsection{Characteristics of the banks}

Like Hannan and Pilloff (2009) and Hernando et al. (2009), we use two accounting measures of operating performance: ${ }^{7}$ a measure of efficiency and a measure of profitability. Efficiency is measured with the cost to income ratio, defined as operating costs divided by operating income: as known, the higher the ratio, the lower the level of cost efficiency. Profitability is measured with the return on assets (ROA), that is, the ratio of profit before tax to total assets: ${ }^{8}$ the higher the ratio, the higher the bank's overall returns given its size.

In Table 4, we report the sample means of banks' characteristics across the different kinds of deal. The descriptive statistics provide some preliminary evidence that is broadly in line with the literature on the market for corporate control and the evidence that acquisition mainly transfer assets from underperforming managers to better managers (among others: Cornett et al., 2006;

\footnotetext{
${ }^{7}$ Our setting is similar to that of Hannan and Pilloff (2009) and Hernando et al. (2009), since we focus on pre-deal banks' characteristics and on accounting measures of performance. However, in the multivariate analysis, we use a different econometric specification, since our research questions relate to banks involved in M\&A deals, rather than banks' probability of being involved in a deal.

${ }^{8}$ We use the return on assets (ROA), instead of the return on equity (ROE), since our sample is worldwide and the ROA is better-equipped in a cross-country analysis of banks with different levels of capitalization and leverage (Rivard and Thomas, 1997; Athanasoglou et al., 2008; Kosmidou, 2008).
} 
Beccalli and Frantz, 2009; Evanoff and Ors, 2008; Lel and Miller, 2015; Hannan and Pilloff ,2009; Hernando et al., 2009).

As shown in Table 4, the ROA of the acquirers (1.14\%) is on average higher than the ROA of the targets $(1.01 \%)$. The evidence is even stronger for the cost to income measure of efficiency: on average, the acquirer's cost to income ratio is lower than that of the target $(64.11 \%$ and $73.71 \%$, respectively), consistent with the idea that acquirers prefer target banks with opportunities for cost saving. Acquirers also have a higher level of capitalization, as well as a better-performing loan portfolio.

Moving to the four types of deals, with due caution because these descriptive statistics do not control for potential covariates (see below), the cost to income measure of performance supports the view that less efficient banks are acquired by more efficient banks in all the four types of deal. There are, however, some differences suggesting that ownership matters. Indeed, the value of the cost to income ratio is significantly lower for state-owned acquirers than for their private benchmarks; moreover, state-owned banks acquire targets that are less efficient but, at the same time, healthier on average than targets acquired by privately owned banks. Moreover, the ROA of the acquirer is higher than the ROA of the target both when the acquirer is a privately owned bank and when the acquirer is a state-owned bank. However, while the ROA of the acquirer is similar for state-owned and private banks, the data highlight that the ROA of the targets involved in public reorganization deals is higher that of the targets of private acquirers.

\subsection{Development versus commercial state-owned banks}

In this descriptive section, we also investigate (Table 5) the differences between development and commercial state-owned banks in the MCC, given that, as highlighted in the Introduction, these two groups of state-owned banks may have different missions and business models, serve different targets of customers and offer different types of products and services.

Within our sample, the data confirm relevant differences between the two groups of state-owned banks. Development banks are more efficient and more profitable than commercial state-owned banks; their performance is also better than that of private banks. Specifically, the ROA of development banks (2.05\%) is four times the ROA of state-owned commercial banks $(0.54 \%)$, and it is almost double that of private banks (1.14\%). A similar relation holds for the efficiency measure: the cost-income ratio of development banks is lower than the others; within commercial banks, state-owned banks highlight better efficiency than private banks. Interestingly, the data also display a better loan portfolio quality for development banks: the impaired loans to gross loans ratio is $3.58 \%$ for development banks, while it is $5.20 \%$ for private banks and $9.16 \%$ for commercial state-owned banks. This is in line with the evidence from the World Bank (2013) that highlights that on average the non-performing loan ratio of development banks is below the national average. ${ }^{9}$ As far as commercial state-owned banks are concerned, it is likely that the low quality of their loan portfolios is burdened by non-performing loans of private banks rescued during the crisis, or by social and political factors.

Another interesting piece of evidence is related to the level of the retail deposit to total funding ratio. This ratio is a proxy for the retail activity of the bank on the liability side: the higher the ratio, the higher the amount of funding raised by means of the current account, saving deposits and other types of financial instruments typically offered by banks to retail customers. In our sample, the relative weight of retail funding in the overall funding activity is similar for commercial stateowned and private banks (respectively $74.4 \%$ and $69.6 \%$ ), while it is much lower for development

\footnotetext{
${ }^{9}$ Specifically, in $2009,39 \%$ of development banks had a non-performing loan ratio higher than their national average, while $64 \%$ of development banks were below the national average; the percentage of development banks with a better ratio was rising compared with previous years.
} 
banks (43.8\%). Indeed, while commercial banks fund their business activity with a mix of different sources, among which are taking savings and deposits from the public, development banks mainly raise funds by borrowing from other financial institutions or issuing debt (World Bank, 2013). Development banks also have a solvency ratio, measured by the equity to total asset ratio, which is more than twice that of commercial state-owned banks and higher than that of private banks.

Overall, while commercial banks, both state-owned and privately owned, have similar ratios, development banks display different levels, thus highlighting the different nature of this type of government-owned banks.

Within such a context, we now move away from the descriptive statistics, and focus on the characteristics of banks acting as acquirers in MCC.

\section{The research methodology}

The empirical analysis aims to test for any systematic difference in bank operating performance that might be explained by differences in the ownership structure of banks involved as acquirers in M\&A deals. We first estimate a regression model to examine whether profitability and cost efficiency vary across state-owned and privately owned banks acting as acquirers in the MCC. A second regression model will also be estimated to focus on the question of whether such performance indicators are connected to the specific type of deal in which the acquirer is involved.

\subsection{The acquirer's performance and ownership}

The linear regression model that we use is the following:

$P_{i}=\alpha+\beta_{\text {own }} o w n_{i}+\beta_{\mathrm{bs}}{ }^{\prime} b s_{i}+\beta_{\mathrm{ds}}{ }^{\prime} d s_{i}+\varepsilon_{\mathrm{i}}$

where $P_{i}$ is a measure of the performance of the acquirer $i$ and $o w n_{i}$ is a dummy variable related to the ownership of the acquirer, while $b s_{i}$ and $d s_{i}$ are vectors of control variables referring to bank and deal characteristics, respectively. The term $\varepsilon_{i}$ is the usual error term. Although not explicitly indicated to simplify the notation, all the explanatory variables refer to the year before the date of the deal to avoid endogeneity and because we are interested in the firms' characteristics before they merge.

The performance of the acquirer is captured, alternatively, by the measure of efficiency (cost to income $_{i}$ ) and the measure of profitability $\left(R O A_{i}\right)$ described in Section 3.2, as commonly discussed in the literature. Our ownership structure is a dummy that equals 1 if the bank is state-owned and 0 otherwise $\left(o w n_{i}\right)$. We have already described in detail the identification process of ownership. The expected sign and magnitude of the coefficient related to the ownership variable represent the main object of the investigation. Traditionally, state-owned banks are said to be less profitable and efficient than privately owned banks. If this were true also for those state-owned banks that engage in deals, the coefficient sign would therefore be negative - as far as the ROA is concerned - and positive - as far as the cost to income ratio is concerned.

As control variables we use bank-specific variables for size, capitalization, type of activity and asset quality. The log of total assets is the proxy for the bank's size (Assets $)_{i}$. Generally, the effect of an increase in the size of the bank has been proved to be positively related to profitability due to better diversification opportunities and the lower cost of funding of larger banks compared with smaller banks (Molyneux and Thorton, 1992; Demirgug-Kunt and Huizinga, 2000; Bikker and Hu, 2002; Goddard et al., 2004). However, other studies suggest that the positive effect of increased 
bank size on profitability may be positive up to a certain limit, while beyond this point marginal cost savings can be achieved by greater size (Athanasoglou et al., 2008).

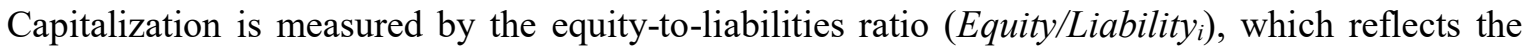
level of a bank's protection against asset malfunctions. Bank leverage and capitalization are analysed in depth in the previous literature, but the empirical results vary significantly. The effect of bank capitalization on profitability is generally found to be positive. An increase in capital reduces the expected costs of bankruptcy; the lower likelihood of financial distress results in a lower cost of funding, leading to a positive impact on bank profitability. Moreover, banks with relatively low capital respond to moral hazard incentives by increasing the riskiness of their loan portfolio, resulting in higher non-performing loans on average in the future (Molyneux and Thorton, 1992; Dermiguc-Kunt and Huizinga, 2000; Goddard et al., 2004; Mehran and Thakor, 2011). However, there are also findings of a negative relationship between profits and equity. A relatively high capital-assets ratio could indicate that a bank is operating over-cautiously, ignoring potentially profitable diversification or other opportunities and using more equity, which is more expensive than debt (Angbazo, 1997; Goddard et al., 2004).

The type of banking activity is measured by the ratio of retail deposits to total funding (Retail deposit/Total funding $i$ ). This ratio captures the relative importance of traditional intermediation activity. We also consider the ratio of net loans to retail funding (Loans/Retail funding ${ }_{i}$ ), an indicator that captures the degree of liquidity of the bank. Asset quality is proxied by the nonperforming loans to gross loans ratio; the higher the ratio, the poorer the quality of the loan portfolio (Nonperforming loans/Loans $i$ ). The effect of credit risk on profitability is usually negative; the greater the exposure to high-risk loans, the greater the accumulation of loan losses, as well as higher costs on loan monitoring implying a reduction in profitability (Miller and Noulas, 1997).

Moreover, as discussed in detail in Section 3.3, there is a substantial difference between development and commercial state-owned banks acting as acquirers in the market for corporate control. To control for the different natures of these two groups of banks, we include a further dummy variable assuming the value 1 for development banks acting as acquirers and 0 otherwise (Dev. Banks $)_{\text {). }}$

Finally, to control for country-specific and time-specific effects, we include, as further regressors collected in $d s_{i}$, dummy variables for the macro area of the acquirer and for the year of the deal.

\subsection{The acquirer's performance and type of deal}

In a second set of empirical models, we want to examine whether operating performances vary according to the four types of deal involving the acquirer bank, namely public reorganization, publicization, privatization and private reorganization. The model, thus, can be written as:

$P_{i}=\alpha+\beta_{\mathrm{PR}}$ PubReorg $_{i}+\beta_{\mathrm{Pu}}$ Publ $_{i}+\beta_{\mathrm{Pr}}$ Privi $_{i}+\beta_{\mathrm{bs}}$ ' $b s_{i}+\beta_{\mathrm{ds}}{ }^{\prime} d s_{i}+\varepsilon_{\mathrm{i}}$.

As before, $P_{i}$ represents the performance of the acquirer (either ROA or cost to income ratio), while the three dummies PubReorg ${ }_{i}$ Publ $_{i}$ and Privi $i$ indicate public reorganization, publicization and privatization, respectively. Being the most represented in our sample, private reorganization is chosen as the reference group. Moreover, in deals between private banks on both sides of the transaction, there is no need to assume deviation from the objective of wealth maximization by the managers. This offers a natural benchmark to read the estimated coefficients in terms of deviation from efficient behaviour. The related coefficients $\beta_{\mathrm{PR}}, \beta_{\mathrm{Pu}}$ and $\beta_{\mathrm{Pr}}$ indicate the extent to which the type of deal explains the performance of the acquirer. Likewise, in the previous model, a set of 
bank-specific $\left(b s_{i}\right)$ and deal-specific $\left(d s_{i}\right)$ variables is included in the regression model; again, to account for the different nature of state-owned banks, we also add a dummy that equals 1 if the acquirer is a development bank and 0 otherwise.

\section{Results}

In this section, we report a set of results obtained by estimating the linear regression models presented in Section 4. We distinguish the findings according to the different models designed for explaining a) the relationship between the performance of the acquirer and its ownership; and b) the acquirer's performance and the type of deal.

\subsection{The acquirer's performance and ownership}

Tables $6 \mathrm{a}$ and $6 \mathrm{~b}$ report the results of the estimated regression model presented in Eq. (1). Our null hypothesis is that the ownership of the acquirer bank plays no role, implying that state-owned banks that are active in the market for corporate control have the same characteristics as their private benchmarks in terms of efficiency and profitability. In Eq. (1), testing for this null hypothesis corresponds to checking the significance of the coefficient $\beta_{\text {own. }}$. In the case of null rejection, it becomes interesting to evaluate the sign and magnitude of the coefficient to shed light on the different characteristics of the acquiring banks in terms of efficiency and profitability.

Table 6a presents the results of the estimated model when the cost to income ratio is the dependent variable. In all the specifications, the coefficient of the ownership variable is negative and always statistically significant at the $1 \%$ level. This finding suggests that, even controlling for other bankspecific and deal-specific variables, the segment of state-owned banks active in MCC have lower cost to income ratios than their private counterparts. The coefficient is still significant when we distinguish between development and commercial state-owned banks but is stronger for development banks, as already suggested by Table 5 . This evidence may seem surprising given the wide literature on the poor performance of state-owned banks. However, we observe here a specific segment of state-owned banks, those that are active as acquirers in the MCC, hence a particularly dynamic group. The signs of the control variables that are statistically significant are coherent with the existing empirical and theoretical literature; in particular, size negatively affects inefficiency given the positive role of economies of scales. ${ }^{10}$

Table $6 \mathrm{~b}$ reports the estimated coefficients when the dependent variable is the ROA. In all the specifications but the first, the coefficient of the ownership variable is not statistically significant, suggesting that ownership doesn't make a difference for the pre-deal profitability of acquirers. The signs of the control variables are again in line with the expectations; in particular, the impaired loans to gross loans ratio negatively affects bank performances, while the level of capitalization has a positive impact. Interestingly, the sign of the development bank dummy variable is negative and statistically significant.

\subsection{The acquirer's performance and type of deal}

\footnotetext{
${ }^{10}$ Interestingly, but not reported here to save space, the crucial year of the Great Recession has a positive and statistically significant sign for all the acquirers. Details can be provided by the authors upon request.
} 
Tables $7 \mathrm{a}$ and $7 \mathrm{~b}$ report results designed to address the question of whether the characteristics (in term of performance) of the acquirers are different according to the four types of deal in which they are involved. As far as the efficiency of the banks is concerned (Table 7a), captured by the cost to income measure of performance, both types of deal performed by state-owned banks as acquirers have negative and statistically significant coefficients. These results are robust to all the specifications and are stronger for development banks.

Moving to the profitability, measured by the ROA (Table $7 \mathrm{~b}$ ), the only type of deal that is statistically significant is public reorganization: state-owned banks acquiring state-owned targets have a higher ROA than the other acquirers involved in M\&A deals. This result, however, weakens when controlling for the time effect, in which a positive and significant coefficient emerges for the first year of the global financial crisis, when, probably, only the most profitable banks (both private and state-owned) remained in the M\&A arena on the acquirer's side.11

A focus on comments and rationales reported on the deals performed by state-owned banks (source Zephir) reveals interesting features that contribute understanding the motivations behind M\&As and gaining insight into the nature of banks active in the MCC. A relevant part of the deals performed by our sample of state-owned banks seems having a shareholder value maximization motivation, in particular when development banks, all with sound balance sheet, are involved as acquirers. For example, the French Caisse des Depots et Consignations has been involved as acquirer in deals - mainly domestic - that were made as investments in different strategic sectors, such as high speed telecommunication networks (Manche Télécom Participation SA, Moselle Télécome SAS; Iris $64 \mathrm{SA}$ ), biodiesel producers (Soprol SA), biomass project developers (Biomelec SAS), water treatment companies (Séché Environment SA). The European Bank for Reconstruction \& Development - EBRD has also been involved in deals with target mainly in the financial - bank and insurance - sector (e.g. Vseobacna Uverova Banka - Slovak; Insig - Albania; Lietuvos Droudimas - Lithuania) and in the utilities, including energy and water (e.g. Zapadoslovenska Energetika - Slovak; Tallina Vesi - Estonian; Sofiyska Voda - Bulgaria). These deals were mainly aimed at supporting the development of strategic sectors in different countries, applying policies related to the evaluation of projects related not only to social and environmental performance of the investment in the host economy, but also to the development's bank financial performance and the generation of economic rate of returns (MfDR, 2015). In the sample there are also deals performed by banks that during the 2008 crisis received state-aid because of financial troubles (e.g. Bayerische Landsbank, Royal Bank of Scotland, Allied Irish Bank, Bainf - Banco de Investimiento), and whose performance measures are unavoidably low, although they are recovering and the deals they performed, as describer in the rationales reported by Zephir, are likely to have shareholders value maximization motivation, related to cross-border diversification and market power (e.g. the acquisition of the Austrian Hypo Alpe-Adria Bank International AG by the German Bayerische Landesbank in 2011, or the deal involving in 2013 the Royal Bank of Scotland as acquirer and Société Foncière Lyonnaise SA, the French property investment company as target). We finally detected a different type of M\&A motivation, were the development bank act as facilitator of government's intention to privatize part of State-owned Enterprises. This is the case of deals performed by KfW during the period 2007-2009, with the German Government as vendor and Deutsche Post and Deutsche Telekom as targets. In these cases, the Government aimed at selling stakes in SOEs to the development bank and then, waiting for more favourable market conditions and selling them on stock exchanges.

\footnotetext{
${ }^{11}$ Details on the estimated time effects can be provided by the authors upon request.
} 


\section{Robustness checks}

\subsection{Non-linear relations between performance and its determinants}

When modelling bank performance, it is not unlikely that non-linearity will emerge among the variables involved in the analysis. In all the regressions, we searched for such potential nonlinearity, mainly considering interactions and/or polynomial relations. In all the tables presented in the paper, we report the unique form of non-linearity that significantly enters the results, namely the quadratic effect of the size of the acquirer bank. In all cases, both the linear and the quadratic effects are significantly different from zero and of the expected sign. In Tables $6 a$ and $7 a$, focusing on the efficiency of the acquirer, the linear coefficient is always negative, indicating that larger banks are more likely to reduce the cost to income indicator, but when introducing the quadratic term, it emerges that such a relation is not linear and the benefits of being large reduce as the dimension increases. Similar results are obtained in Tables $6 \mathrm{~b}$ and $7 \mathrm{~b}$, for the performance of the acquirers, measured by the ROA before taxes.

\subsection{Country cluster heterogeneity}

In this second robustness exercise, we ask whether the main results that we found in terms of the relations between bank performance, ownership and type of deal change when we restrict the analysis to a homogeneous (regarding their nature) group of countries. ${ }^{12}$ In particular, we focus on 1) Western EU countries, 2) OECD countries, 3) BRICST countries, ${ }^{13} 4$ ) developing countries and 5) graduated developing countries ${ }^{14}$. For each of these groups, we repeat our regression analysis and compare the results.

In Tables $8 \mathrm{a}$ and $8 \mathrm{~b}$, we show the estimated results for all the clusters of countries when the dependent variables are the cost to income indicator or the ROA indicator, respectively. Such results should be compared with the corresponding estimates reported in Tables $6 \mathrm{a}$ and $6 \mathrm{~b}$, when all the countries were involved in the analysis.

In particular, focusing on the efficiency of the acquirer banks (Table 8a), it clearly emerges that the main results are confirmed when restricting the analysis to Western EU countries, OECD countries and BRICST countries, for which the coefficient of the state-owned dummy variable is negative and strongly significant. Furthermore, for these three groups of countries, the highest efficiency indicators have to be ascribed to state-owned development banks, the coefficient of the associated dummy variable being negative and strongly significant.

In terms of the profitability of the acquirer banks (Table $8 \mathrm{~b}$ ), the results broadly confirm the overall results reported in Table $6 \mathrm{~b}$, indicating that state-owned banks do not have a significantly different ROA from private banks. Moreover, when restricting the analysis to Western EU and OECD countries, the coefficient enters the regression negatively, indicating that private acquirers

${ }^{12}$ The details of the composition of these clusters can be obtained from the IMF or the World Bank website.

${ }^{13}$ Brazil, Russia, India, China, South Africa and Turkey.

${ }^{14}$ According to the IMF and the World Bank: Hong Kong, Israel, Singapore, South Korea, Taiwan, Qatar, Cyprus, Slovenia, Malta, the Czech Republic, Slovakia, Estonia, San Marino, Croatia, Latvia and Lithuania. 
have a higher profitability than state-owned ones. Such significant relations, however, disappear when we introduce the distinction between development and commercial banks.

\subsection{Performances, types of deal and development vs. commercial banks}

In many regressions, we obtained clearly different behaviour between commercial and development state-owned banks. In this section, we delve deeper and investigate the performances of acquirer commercial or development state-owned banks involved in publicization or public reorganization, when compared with similar private acquirers. The results, reported in Table 9, confirm that, when observing profitability, state-owned commercial banks involved in public reorganization are characterized by higher performances than all the others. Considering efficiency, instead, development state-owned banks involved in both public reorganization and publicization have the best performance.

\subsection{The performance of acquirers involved in domestic or cross-border acquisitions}

In a recent contribution, although in a slightly different context, Hernando et al. (2009) distinguished between domestic and cross-border acquisitions. In our framework, we estimate a set of regressions restricting the sample to either the domestic or the cross-border deals. The results, not reported here to save space (available with the authors), do not show any substantial difference across the two groups of deals and confirm the overall results discussed in the previous sections.

\section{Concluding remarks}

In the last decade, the empirical evidence from the strand of literature that analyses the issue of the relationship between government ownership and bank performance has been more mixed than in the past, when SOBs appeared inherently less efficient and profitable than private banks. One likely reason of such evidences is that in recent years state-owned banks have been reorganized, converted into limited liability corporations and shareholder companies and subjected to the same accounting principles, corporate governance practices and regulatory frameworks as privately owned banks (OECD, 2012). A number of countries, although not all, have undertaken important reforms to empower state-owned banks' boards, to shield them from political intervention and increase their autonomy and to enhance their competence through skill-based nomination processes (OECD, 2005, 2011). Those global changes potentially work in the direction of aligning the operational mechanisms of state-owned and privately owned banks facing similar issues and challenges.

This intuition is broadly confirmed by our findings, at least for a part of the industry, that is SOBs that are acquirers in the market for corporate control and, therefore, are actively participating to the recent expanding role of governments. Our main result is that the pre-deal performances of those state-owned banks that play the role of acquirer in the market for corporate control, after controlling for other bank-specific and deal-specific variables, are similar (looking at the ROA) or better (looking at the cost to income ratio) relative to their private counterparts . The result holds when we distinguish between development and commercial state-owned banks, but is stronger for development banks. A battery of robustness tests confirms our findings.

This paper contributes to the debate on state-owned banks from an entirely new perspective, as we focus exclusively on those banks that are active in the market for corporate control. State-owned banks in previous literature were often considered unique entities characterized by poor performance for a variety of reasons, but ultimately for political interference in their governance and operations. Our findings suggest that in the last decade a sub-set of state-owned banks, those that we observe as active players in the market for corporate control, are at least as efficient and 
profitable as their private benchmark. We have also pointed to differences between development and commercial state-owned banks, with the former performing better than the latter. Hence, it would be interesting to understand the mechanisms that have recently allowed some types of stateowned banks to emerge as potential competitors of private firms in the market for corporate control. Are the performance that we observe in the last decade the consequence of special protection by governments to such banks or are governments appointing better managers and giving more autonomy to them? We leave this question for further research. 


\section{References}

Altman, E.I. 1993. Corporate Financial Distress and Bankruptcy. Wiley, New York.

Altunbas, Y. and Marques, D. 2008. Mergers and acquisitions and bank performance in Europe. The role of strategic similarities. Journal of Economics and Business 60: 204-222.

Angbazo, L. 1997. Commercial bank net interest margins, default risk, interest rate risk and off balance sheet activities. Journal of Banking and Finance 2: 55-87.

Athanasoglou, P.P., Brissimis, S.N. and Delis, M.D. 2008. Bank-specific, industry-specific and macroeconomic determinants of bank profitability. Journal of International Financial Markets, Institutions and Money 18: 121-136.

Atkinson, A.B. and Stiglitz, J.E. 1980. Lecture on Public Economics. McGraw-Hill, London.

Beccalli, E. and Frantz, P. 2009. M\&A operations and performance in banking. Journal of Financial Service Research: 36.

Berger, A.N., Clarke, G.R.G., Cull, R., Klapper, L. and Udell, G.F. 2005. Corporate Governance and Bank Performance: A Joint Analysis of the Static, Selection, and Dynamic Effects of Domestic, Foreign, and State Ownership. World Bank Policy Research Working Paper, 3632.

Bikker, J.A. and Hu, H. 2002. Cyclical patterns in profits, provisioning and lending of banks and procyclicality of the new Basel capital requirements. BNL Quarterly Review 221: 143-175.

Bortolotti, B. and Faccio, M. 2009. Government control of privatized firms. Review of Financial Studies 22(8): 2907-2939.

Carvalho, D. 2014. The real effects of government-owned banks: evidence from an emerging market. Journal of Finance 69(2): 577-609.

Chen, P. and Liu, P. 2013. Bank ownership, performance, and the politics: evidence from Taiwan. Economic Modeling 31: 578-585.

Cornett, M.M., McNutt, J.J. and Tehranian, H. 2006. Performance changes around bank mergers: revenue enhancements versus cost reductions. Journal of Money, Credit and Banking 38: 10131050.

Cornett, M.M., Lin, G., Khaksari, S. and Tehranian, H. 2009. The impact of state ownership on performance differences in privately-owned versus state-owned banks: an international comparison. Journal of Financial Intermediation 19: 74-94.

Demirgug-Kunt, A. and Huizinga, H.P. 2000. Financial Structure and Bank Profitability. Policy Research Working Paper Series 2430. The World Bank, Washington.

De Young, R., Evanoff, D.D. and Molyneux, P. 2009. Mergers and acquisitions of financial institutions: a review of the post-2000 literature. Journal of Financial Services Research 36: 87110. 
European Commission. 2014. State Aid Scoreboards. DG Competition.

Evanoff, D.D. and Örs, E. 2008. The competitive dynamics of geographic deregulation in banking: implications for productive efficiency. Journal of Money, Credit and Banking 40: 897-928.

Figuera, C., Nellis, J. and Parker, D. 2009. The effects of ownership on bank efficiency in Latin America. Applied Economics 41: 2353-2368.

Florio, M. 2013, Network industries and social welfare. The experiment that reshuffled European utilities, Oxford University Press.

Frydman, R., Gay, C., Hessel, M. and Rapaczynski, M. 1999. Private ownership and corporate performance: evidence from the transition economies. Quarterly Journal of Economics 114: 11531192.

Gerschenkron, A. 1962. Economic Backwardness in Historical Perspective. Harvard University Press, Cambridge, MA.

Goddard, J., Molyneux, P. and Wilson, J.O.S. 2004. Dynamics of growth and profitability in banking. Journal of Money, Credit and Banking 36: 1069-1090.

Hannan, T.H. and Pilloff, S.J. 2009. Acquisition targets and motives in the banking industry. Journal of Money, Credit and Banking 41(6): 1168-1187.

Hernando I., Nieto, M.J. and Wall, L.D. 2009. Determinants of domestic and cross-border bank acquisitions in the European Union. Journal of Banking and Finance 33: 1022-1032.

Iannotta, G., Nocera, G. and Sironi, A. 2007. Ownership structure, risk and performance in the European banking industry. Journal of Banking and Finance 31: 2127-2149.

Jensen, M.C. and Ruback, R. 1983. The market for corporate control: the scientific evidence. Journal of Financial Economics April: 5-50.

Jiang, C., Yao, S. and Feng, G. 2013. Bank ownership, privatization, and performance: evidence from a transition country. Journal of Banking and Finance 37: 3364-3372.

Karolyi A.G., Liao R.C. 2015. State Capitalism's Global Reach: Evidence from Foreign Acquisitions by Sovereign Acquirers. Journal of corporate finance (forthcoming)

Kornai, J. 1979. Resource-constrained versus demand-constrained systems. Econometrica 47: 801-819.

Kosmidou, K. 2008. The determinants of banks' profits in Greece during the period of EU financial integration. Managerial Finance 34: 146-159.

Laffont, J.J., Tirole J. 1993. A Theory of Incentives in Procurement and Regulation. MIT Press, Cambridge, MA.

La Porta, R., Lopez-de-Silanes, F. and Shleifer, F. 2002. Government ownership of banks. Journal of Finance 57 (1): 265-301.

Lel, U. and Miller, D. 2015. Does takeover activity cause managerial discipline? Evidence from international M\&A laws. Review of Financial Studies 28 (6): 1588-1622. 
Manne, G.H. 1965. Mergers and the market for corporate control. Journal of Political Economy 73: $110-120$.

Mazzuccato, M. and Penna, C.R 2014. Beyond market failures. The market creating and shaping roles of state investment banks. SPRU Working paper series 21:1-35.

MfDR 2015. The Common Performance Assessment System of the Multilateral Development Bank. Annual Report.

Mehran, H. and Thakor, A. 2011. Bank capital and value in the cross-section. Review of Financial Studies 24(4): 1019-1067.

Micco, A., Panizza, U. and Yanez, M. 2007. Bank ownership and performance. Does politics matter? Journal of Banking and Finance 31: 219-241.

Miller, S. and Noulas, A. 1997. Portfolio mix and large-bank profitability in the USA. Applied Economics 29: 505-512.

Molyneux, P. and Thorton, J. 1992. Determinants of European bank profitability: a note. Journal of Banking and Finance 16: 1173-1178.

Musacchio A., Lazzarini S.B, 2014, Reinventing State Capitalism. Leviathan in Business, Brazil and beyond, Harvard University Press, Cambridge (Mass.), London

OECD. 2005. The board of directors of a state-owned enterprise. In Corporate Governance of State-Owned Enterprises: A Survey of OECD Countries. OECD Publishing, Paris.

OECD 2010. The Size and Composition of the SOE Sector in OECD and other Countries. OECD Publishing, Paris.

OECD. 2011. Corporate Governance of State-Owned Enterprises: Change and Reform in OECD Countries since 2005. OECD Publishing, Paris.

OECD. 2012. Global Survey of Development Banks. Policy Research Working Paper 5969, February.

OECD. 2014. The Size and Sectorial Distribution of SOEs in OECD and Partner Countries. OECD Publishing, Paris.

Pargendler M., Musacchio A. and Lazzarini S. 2013. In Strange Company: The Puzzle of Private Investment in State-Controlled Firms. Cornell International Law Journal 46: 569.

Rivard, R.J. and Thomas, C.R. 1997. The effect of interstate banking on large bank holding company profitability and risk. Journal of Economics and Business 49: 61-76.

Shleifer, A. and Vishny, R.W. 1994. Politicians and firms. Quarterly Journal of Economics 109(4): 995-1025.

Shleifer, A. and Vishny, R.W. 1997. A survey of corporate governance. Journal of Finance LII(2): 737-783 . 
Stiglitz, J.E. 1993. The role of the state in financial markets. Proceedings of the World Bank Annual Conference on Economic Development. Washington DC, World Bank, 19-56.

World Bank. 2011. Development Banks: Role and Mechanisms to Increase their Efficiency. Policy Research Working Paper 5729.

World Bank. 2013. Rethinking the Role of the State in Finance. Global Financial Development Report. 


\section{Tables}

Table 1. Number of deals by ownership of acquirer and target

\begin{tabular}{|c|c|c|c|c|}
\hline \multicolumn{5}{|c|}{ Target } \\
\hline & & State-owned & Private & Total \\
\hline \multirow{3}{*}{ Acquirer } & State-owned & $111(3 \%)$ & $256(7 \%)$ & $367(10 \%)$ \\
\hline & Private & $441(12 \%)$ & $2,874(78 \%)$ & $3,315(90 \%)$ \\
\hline & Total & 552 (15\%) & 3,130 (85\%) & $3,682(100 \%)$ \\
\hline
\end{tabular}

Source: our elaboration on data from Zephir and Bankscope, Bureau van Dijk.

Table 2. Number of deals by year and type of ownership

\begin{tabular}{|c|c|c|c|c|c|}
\hline \multirow[t]{2}{*}{ Year } & \multicolumn{5}{|c|}{ Numbers of deals } \\
\hline & Public reorganization & Publicization & Privatization & Private reorganization & Total \\
\hline 2003-2008 & $16(0.4 \%)$ & $42(1.2 \%)$ & $85(2.3 \%)$ & $402(10.9 \%)$ & $545(14.8 \%)$ \\
\hline $2009-2013$ & $95(2.6 \%)$ & $214(5.8 \%)$ & $356(9.7 \%)$ & $2,472(67.1 \%)$ & $3,137(85.2 \%)$ \\
\hline Total & $111(3 \%)$ & $256(7 \%)$ & 441 (12\%) & $2,874(78 \%)$ & $3,682(100 \%)$ \\
\hline
\end{tabular}

Source: our elaboration on data from Zephir and Bankscope, Bureau van Dijk. 
Table 3. Number of domestic and cross-border deals (acquirers)

\begin{tabular}{lccc}
\hline Macroarea & \multicolumn{3}{c}{ Number of deals } \\
\cline { 2 - 4 } Africa & Domestic & Cross-border & Total \\
Eastern Europe & $574(1.9 \%)$ & $18(0.5 \%)$ & $54.4 \%)$ \\
Far East and Central & $418(11.8 \%)$ & $15(0.4 \%)$ & $589(16.6 \%)$ \\
Asia & $35(1.0 \%)$ & $453(12.7 \%)$ \\
Middle East & $43(1.2 \%)$ & $23(0.6 \%)$ & $66(1.9 \%)$ \\
North America & $354(10.0 \%)$ & $190(5.3 \%)$ & $544(15.3 \%)$ \\
Oceania & $17(0.5 \%)$ & $17(0.5 \%)$ & $34(1.0 \%)$ \\
South and Central & $102(2.9 \%)$ & $27(0.8 \%)$ & $129(3.6 \%)$ \\
America & & $327(9.2 \%)$ & $1,655(46.6 \%)$ \\
Western Europe & $1,328(37.4 \%)$ & $\mathbf{6 5 2}(\mathbf{1 8 . 3 \%})$ & $\mathbf{3 , 5 5 4 ( 1 0 0 . 0 \% )}$ \\
\hline Total (*) & $\mathbf{2 , 9 0 2 ( 8 1 . 7 \% )}$ & &
\end{tabular}

Sources: our elaboration on data from Zephyr (BvD) and Bankscope (BvD). $\left(^{*}\right)$ The totals are different since not all the data have information about the country variable. 


\begin{tabular}{|c|c|c|c|c|c|}
\hline & $\begin{array}{c}\text { Public } \\
\text { reorganization }\end{array}$ & Publicization & Privatization & $\begin{array}{c}\text { Private } \\
\text { reorganization }\end{array}$ & Total \\
\hline ROA (A) & 1.41 & 1.25 & 1.46 & 1.10 & 1.14 \\
\hline ROA (T) & 1.28 & 1.10 & 0.81 & 1.02 & 1.01 \\
\hline Cost to income ratio (A) & 44.76 & 51.59 & 61.71 & 67.66 & 64.11 \\
\hline Cost to income ratio (T) & 60.87 & 63.21 & 70.51 & 76.00 & 73.71 \\
\hline Impaired loans/gross loans (A) & 8.51 & 5.21 & 4.63 & 5.29 & 5.45 \\
\hline Impaired loans/gross loans ( $\mathrm{T}$ ) & 6.73 & 7.33 & 6.51 & 6.27 & 6.39 \\
\hline Retail deposit/total funding (A) & 69.79 & 55.54 & 75.59 & 68.63 & 67.91 \\
\hline Retail deposit/total funding (T) & 77.76 & 78.03 & 81.38 & 72.25 & 74.20 \\
\hline Net loan/retail funding (A) & 107.05 & 118.70 & 72.85 & 89.32 & 91.80 \\
\hline Net loans/retail funding $(\mathrm{T})$ & 121.48 & 89.48 & 88.99 & 107.99 & 104.45 \\
\hline Equity/total assets (A) & 13.27 & 19.30 & 14.17 & 14.70 & 15.12 \\
\hline Equity/total assets $(\mathrm{T})$ & 14.33 & 14.49 & 13.13 & 14.16 & 14.04 \\
\hline Total assets (A) (millions Euro) & 80,914 & 143,719 & 156,526 & 153,297 & 149,014 \\
\hline Total assets (T) (millions Euro) & 29,344 & 59,286 & 26,343 & 18,643 & 23,318 \\
\hline No. of obs. & 109 & 250 & 441 & 2.874 & 3.674 \\
\hline
\end{tabular}

Source:our elaboration on data from Zephir and Bankscope, Bureau van Dijk.

Table 5. Performance indicators by acquirer type: development banks, commercial state-owned banks and private banks (mean values)

\begin{tabular}{lrrrr}
\hline & $\begin{array}{c}\text { Development } \\
\text { banks }\end{array}$ & $\begin{array}{c}\text { Commercial } \\
\text { state-owned } \\
\text { banks }\end{array}$ & Private banks & Total \\
\hline ROA & 2.05 & 0.54 & 1.14 & 1.17 \\
Cost to income ratio & 40.15 & 59.19 & 66.88 & 64.09 \\
Impaired loans/gross loans & 3.58 & 9.16 & 5.20 & 5.38 \\
Retail deposit/total funding & 43.78 & 74.40 & 69.55 & 67.81 \\
Net loans/retail funding & 149.62 & 80.68 & 87.03 & 91.97 \\
Equity/total assets & 23.96 & 11.11 & 14.63 & 15.10 \\
Total assets (millions Euro) & 104,196 & 151,479 & 153,722 & 149,515 \\
No. of obs. & 90 & 89 & 889 & 1,068 \\
\hline
\end{tabular}

Source: our elaboration on data from Zephir and Bankscope, Bureau van Dijk. 
Table 6a. Performance and ownership (OLS regression: dependent variable - cost to income ratio)

\begin{tabular}{|c|c|c|c|c|c|c|c|}
\hline VARIABLES & $\begin{array}{c}(1) \\
\text { OLS } \\
\end{array}$ & $\begin{array}{c}(2) \\
\text { OLS } \\
\end{array}$ & $\begin{array}{c}(3) \\
\text { OLS }\end{array}$ & $\begin{array}{c}(4) \\
\text { OLS }\end{array}$ & $\begin{array}{c}(5) \\
\text { OLS } \\
\end{array}$ & $\begin{array}{c}(6) \\
\text { OLS } \\
\end{array}$ & $\begin{array}{c}(7) \\
\text { OLS } \\
\end{array}$ \\
\hline Own (=1 state-owned) & $\begin{array}{c}-19.26^{* * *} \\
(2.32)\end{array}$ & $\begin{array}{c}-17.98^{* * *} \\
(2.31)\end{array}$ & $\begin{array}{c}-18.36^{* * *} \\
(2.27)\end{array}$ & $\begin{array}{c}-17.23 * * * \\
(2.30)\end{array}$ & $\begin{array}{c}-15.86^{* * *} \\
(2.28)\end{array}$ & $\begin{array}{c}-13.75 * * * \\
(2.18)\end{array}$ & $\begin{array}{c}-6.13^{* *} \\
(2.93)\end{array}$ \\
\hline Dev. Bank (= 1 yes $)$ & & & & & & & $\begin{array}{c}-15.45 * * * \\
(4.02)\end{array}$ \\
\hline Assets & $\begin{array}{c}-1.88 * * * \\
(0.40)\end{array}$ & $\begin{array}{c}-2.56^{* * *} \\
(0.43)\end{array}$ & $\begin{array}{c}-3.44 * * * \\
(0.44)\end{array}$ & $\begin{array}{c}-3.15 * * * \\
(0.45)\end{array}$ & $\begin{array}{c}-3.41 * * * \\
(0.45)\end{array}$ & $\begin{array}{c}-41.88 * * * \\
(4.44)\end{array}$ & $\begin{array}{c}-39.90 * * * \\
(4.43)\end{array}$ \\
\hline Assets (square) & & & & & & $\begin{array}{c}1.15^{* * *} \\
(0.13)\end{array}$ & $\begin{array}{c}1.09 * * * \\
(0.13)\end{array}$ \\
\hline Retail deposit / total funding & $\begin{array}{l}-0.04 \\
(0.04)\end{array}$ & $\begin{array}{c}-0.10 * * \\
(0.04)\end{array}$ & $\begin{array}{c}-0.30 * * * \\
(0.05)\end{array}$ & $\begin{array}{c}-0.31 * * * \\
(0.05)\end{array}$ & $\begin{array}{c}-0.32 * * * \\
(0.05)\end{array}$ & $\begin{array}{c}-0.22 * * * \\
(0.05)\end{array}$ & $\begin{array}{c}-0.27 * * * \\
(0.05)\end{array}$ \\
\hline Nonperforming loans / loans & $\begin{array}{c}0.17 \\
(0.14)\end{array}$ & $\begin{array}{c}0.14 \\
(0.13)\end{array}$ & $\begin{array}{c}0.12 \\
(0.13)\end{array}$ & $\begin{array}{c}0.17 \\
(0.14)\end{array}$ & $\begin{array}{c}0.09 \\
(0.14)\end{array}$ & $\begin{array}{c}0.15 \\
(0.14)\end{array}$ & $\begin{array}{c}0.07 \\
(0.14)\end{array}$ \\
\hline Equity / liability & & $\begin{array}{c}-0.15 * * * \\
(0.04)\end{array}$ & $\begin{array}{c}-0.12 * * * \\
(0.04)\end{array}$ & $\begin{array}{c}-0.11 * * * \\
(0.04)\end{array}$ & $\begin{array}{c}-0.11 * * \\
(0.04)\end{array}$ & $\begin{array}{l}-0.08^{*} \\
(0.04)\end{array}$ & $\begin{array}{l}-0.05 \\
(0.04)\end{array}$ \\
\hline Loans / retail funding & & & $\begin{array}{c}-0.07 * * * \\
(0.01)\end{array}$ & $\begin{array}{c}-0.07 * * * \\
(0.01)\end{array}$ & $\begin{array}{c}-0.07 * * * \\
(0.01)\end{array}$ & $\begin{array}{c}-0.05 * * * \\
(0.01)\end{array}$ & $\begin{array}{c}-0.05^{* * *} \\
(0.01)\end{array}$ \\
\hline Macroarea effects & & & & Yes & Yes & Yes & Yes \\
\hline Time effects & & & & & Yes & Yes & Yes \\
\hline Constant & $\begin{array}{c}98.50 * * * \\
(8.45)\end{array}$ & $\begin{array}{c}116.88^{* * *} \\
\quad(9.52)\end{array}$ & $\begin{array}{c}153.27 * * * \\
(10.74)\end{array}$ & $\begin{array}{c}148.05^{* * *} \\
(10.72)\end{array}$ & $\begin{array}{c}145.52 * * * \\
(13.45)\end{array}$ & $\begin{array}{c}451.55^{* * *} \\
(37.41)\end{array}$ & $\begin{array}{c}439.48^{* * * *} \\
(37.16)\end{array}$ \\
\hline Observations & 702 & 702 & 694 & 690 & 690 & 690 & 690 \\
\hline R-squared & 0.128 & 0.148 & 0.186 & 0.238 & 0.276 & 0.350 & 0.364 \\
\hline
\end{tabular}


Table 6b. Performance and ownership ( OLS regression: dependent variable - ROA before taxes)

\begin{tabular}{|c|c|c|c|c|c|c|c|}
\hline VARIABLES & (1) & (2) & (3) & (4) & (5) & (6) & (7) \\
\hline Own (=1 state-owned) & $\begin{array}{l}0.48^{* *} \\
(0.23)\end{array}$ & $\begin{array}{c}0.13 \\
(0.21)\end{array}$ & $\begin{array}{c}0.14 \\
(0.21)\end{array}$ & $\begin{array}{c}0.07 \\
(0.21)\end{array}$ & $\begin{array}{l}-0.01 \\
(0.21)\end{array}$ & $\begin{array}{c}0.03 \\
(0.21)\end{array}$ & $\begin{array}{c}0.43 \\
(0.28)\end{array}$ \\
\hline Dev. Bank (= 1 yes) & & & & & & & $\begin{array}{c}-0.81 * * \\
(0.38)\end{array}$ \\
\hline Equity & $\begin{array}{l}-0.03 \\
(0.05)\end{array}$ & $\begin{array}{c}0.07 \\
(0.04)\end{array}$ & $\begin{array}{c}0.09 * * \\
(0.04)\end{array}$ & $\begin{array}{c}0.13 * * * \\
(0.04)\end{array}$ & $\begin{array}{c}0.12 * * * \\
(0.05)\end{array}$ & $\begin{array}{c}1.88 * * * \\
(0.45)\end{array}$ & $\begin{array}{c}1.88 * * * \\
(0.45)\end{array}$ \\
\hline Equity (square) & & & & & & $\begin{array}{c}-0.06^{* * *} \\
(0.02)\end{array}$ & $\begin{array}{c}-0.06^{* * *} \\
(0.02)\end{array}$ \\
\hline Retail deposit / total funding & $\begin{array}{l}-0.00 \\
(0.00)\end{array}$ & $\begin{array}{c}0.01 * * \\
(0.00)\end{array}$ & $\begin{array}{c}0.01 * * * \\
(0.00)\end{array}$ & $\begin{array}{c}0.01 \\
(0.01)\end{array}$ & $\begin{array}{c}0.01 \\
(0.01)\end{array}$ & $\begin{array}{c}0.00 \\
(0.01)\end{array}$ & $\begin{array}{c}0.00 \\
(0.01)\end{array}$ \\
\hline Nonperforming loans / loans & $\begin{array}{c}-0.11 * * * \\
(0.01)\end{array}$ & $\begin{array}{c}-0.10 * * * \\
(0.01)\end{array}$ & $\begin{array}{c}-0.10 * * * \\
(0.01)\end{array}$ & $\begin{array}{c}-0.11 * * * \\
(0.01)\end{array}$ & $\begin{array}{c}-0.10 * * * \\
(0.01)\end{array}$ & $\begin{array}{c}-0.10 * * * \\
(0.01)\end{array}$ & $\begin{array}{c}-0.11 * * * \\
(0.01)\end{array}$ \\
\hline Equity / liability & & $\begin{array}{c}0.04 * * * \\
(0.00)\end{array}$ & $\begin{array}{c}0.04^{* * *} \\
(0.00)\end{array}$ & $\begin{array}{c}0.04^{* * *} \\
(0.00)\end{array}$ & $\begin{array}{c}0.04^{* * * *} \\
(0.00)\end{array}$ & $\begin{array}{c}0.04 * * * \\
(0.00)\end{array}$ & $\begin{array}{c}0.04 * * * \\
(0.00)\end{array}$ \\
\hline Loans / retail funding & & & $\begin{array}{c}0.00 * * \\
(0.00)\end{array}$ & $\begin{array}{l}0.00 * \\
(0.00)\end{array}$ & $\begin{array}{c}0.00 \\
(0.00)\end{array}$ & $\begin{array}{c}0.00 \\
(0.00)\end{array}$ & $\begin{array}{c}0.00 \\
(0.00)\end{array}$ \\
\hline Macroarea effects & & & & Yes & Yes & Yes & Yes \\
\hline Time effects & & & & & Yes & Yes & Yes \\
\hline Constant & $\begin{array}{c}2.21 * * \\
(0.86)\end{array}$ & $\begin{array}{l}-0.78 \\
(0.82)\end{array}$ & $\begin{array}{l}-1.71 * \\
(0.93)\end{array}$ & $\begin{array}{c}-1.98 * * \\
(0.92)\end{array}$ & $\begin{array}{l}-1.54 \\
(1.11)\end{array}$ & $\begin{array}{c}-13.30 * * * \\
(3.16)\end{array}$ & $\begin{array}{c}-13.07 * * * \\
(3.15)\end{array}$ \\
\hline Observations & 718 & 718 & 712 & 708 & 708 & 708 & 708 \\
\hline R-squared & 0.093 & 0.252 & 0.256 & 0.310 & 0.356 & 0.371 & 0.375 \\
\hline
\end{tabular}


Table 7a. Performance and type of deal (OLS regression: dependent variable - cost to income ratio)

\begin{tabular}{|c|c|c|c|c|c|c|c|}
\hline VARIABLES & (1) & (2) & (3) & (4) & (5) & (6) & (7) \\
\hline Privatization (dummy) & $\begin{array}{l}-1.02 \\
(2.76)\end{array}$ & $\begin{array}{l}-0.45 \\
(2.73)\end{array}$ & $\begin{array}{l}-1.11 \\
(2.65)\end{array}$ & $\begin{array}{l}-2.50 \\
(2.62)\end{array}$ & $\begin{array}{l}-2.53 \\
(2.59)\end{array}$ & $\begin{array}{l}-1.62 \\
(2.46)\end{array}$ & $\begin{array}{l}-1.62 \\
(2.44)\end{array}$ \\
\hline Publicization (dummy) & $\begin{array}{c}-17.80 * * * \\
(2.73)\end{array}$ & $\begin{array}{c}-16.19^{* * *} \\
(2.73)\end{array}$ & $\begin{array}{c}-16.99 * * * \\
(2.69)\end{array}$ & $\begin{array}{c}-15.74 * * * \\
(2.70)\end{array}$ & $\begin{array}{c}-14.31 * * * \\
(2.67)\end{array}$ & $\begin{array}{c}-12.71 * * * \\
(2.55)\end{array}$ & $\begin{array}{l}-5.02 \\
(3.21)\end{array}$ \\
\hline Public reorganization (dummy) & $\begin{array}{c}-22.77 * * * \\
(3.80)\end{array}$ & $\begin{array}{c}-21.92^{* * *} \\
(3.77)\end{array}$ & $\begin{array}{c}-21.60 * * * \\
(3.66)\end{array}$ & $\begin{array}{c}-21.28 * * * \\
(3.64)\end{array}$ & $\begin{array}{c}-20.06^{* * *} \\
(3.60)\end{array}$ & $\begin{array}{c}-16.60 * * * \\
(3.44)\end{array}$ & $\begin{array}{c}-9.07 * * \\
(3.92)\end{array}$ \\
\hline Dev. Bank (= 1 yes) & & & & & & & $\begin{array}{c}-15.50 * * * \\
(4.02)\end{array}$ \\
\hline Assets & $\begin{array}{c}-1.86^{* * *} \\
(0.40)\end{array}$ & $\begin{array}{c}-2.55 * * * \\
(0.43)\end{array}$ & $\begin{array}{c}-3.42 * * * \\
(0.44)\end{array}$ & $\begin{array}{c}-3.11 * * * \\
(0.45)\end{array}$ & $\begin{array}{c}-3.35 * * * \\
(0.46)\end{array}$ & $\begin{array}{c}-41.48^{* * *} \\
(4.46)\end{array}$ & $\begin{array}{c}-39.48^{* * *} \\
(4.44)\end{array}$ \\
\hline Assets (square) & & & & & & $\begin{array}{c}1.14 * * * \\
(0.13)\end{array}$ & $\begin{array}{c}1.08 * * * \\
(0.13)\end{array}$ \\
\hline Retail deposit / total funding & $\begin{array}{l}-0.03 \\
(0.04)\end{array}$ & $\begin{array}{c}-0.09 * * \\
(0.04)\end{array}$ & $\begin{array}{c}-0.30 * * * \\
(0.05)\end{array}$ & $\begin{array}{c}-0.30 * * * \\
(0.06)\end{array}$ & $\begin{array}{c}-0.31 * * * \\
(0.06)\end{array}$ & $\begin{array}{c}-0.22 * * * \\
(0.05)\end{array}$ & $\begin{array}{c}-0.26 * * * \\
(0.05)\end{array}$ \\
\hline Nonperforming loans / loans & $\begin{array}{c}0.19 \\
(0.14)\end{array}$ & $\begin{array}{c}0.15 \\
(0.13)\end{array}$ & $\begin{array}{c}0.13 \\
(0.13)\end{array}$ & $\begin{array}{c}0.18 \\
(0.14)\end{array}$ & $\begin{array}{c}0.10 \\
(0.14)\end{array}$ & $\begin{array}{c}0.16 \\
(0.14)\end{array}$ & $\begin{array}{c}0.08 \\
(0.14)\end{array}$ \\
\hline Equity / liability & & $\begin{array}{c}-0.15^{* * *} \\
(0.04)\end{array}$ & $\begin{array}{c}-0.12^{* * *} \\
(0.04)\end{array}$ & $\begin{array}{c}-0.11 * * * \\
(0.04)\end{array}$ & $\begin{array}{c}-0.11 * * \\
(0.04)\end{array}$ & $\begin{array}{l}-0.08 * \\
(0.04)\end{array}$ & $\begin{array}{l}-0.05 \\
(0.04)\end{array}$ \\
\hline Loans / retail funding & & & $\begin{array}{c}-0.07 * * * \\
(0.01)\end{array}$ & $\begin{array}{c}-0.07 * * * \\
(0.01)\end{array}$ & $\begin{array}{c}-0.07 * * * \\
(0.01)\end{array}$ & $\begin{array}{c}-0.05 * * * \\
(0.01)\end{array}$ & $\begin{array}{c}-0.05 * * * \\
(0.01)\end{array}$ \\
\hline Macroarea effects & & & & Yes & Yes & Yes & Yes \\
\hline Time effects & & & & & Yes & Yes & Yes \\
\hline Constant & $\begin{array}{c}97.76^{* * * *} \\
(8.49)\end{array}$ & $\begin{array}{c}116.18^{* * *} \\
(9.53)\end{array}$ & $\begin{array}{c}152.44 * * * \\
(10.78)\end{array}$ & $\begin{array}{c}146.80 * * * \\
(10.75)\end{array}$ & $\begin{array}{c}144.08 * * * \\
(13.47)\end{array}$ & $\begin{array}{c}447.68 * * * \\
(37.57)\end{array}$ & $\begin{array}{c}435.46^{* * *} \\
(37.32)\end{array}$ \\
\hline Observations & 702 & 702 & 694 & 690 & 690 & 690 & 690 \\
\hline R-squared & 0.130 & 0.150 & 0.188 & 0.241 & 0.279 & 0.351 & 0.365 \\
\hline
\end{tabular}


Table 7b. Performance and type of deal (OLS regression: dependent variable - ROA before taxes)

\begin{tabular}{|c|c|c|c|c|c|c|c|}
\hline VARIABLES & (1) & (2) & (3) & (4) & $(5)$ & (6) & (7) \\
\hline Privatization (dummy) & $\begin{array}{c}0.41 \\
(0.27)\end{array}$ & $\begin{array}{c}0.26 \\
(0.25)\end{array}$ & $\begin{array}{c}0.27 \\
(0.25)\end{array}$ & $\begin{array}{c}0.18 \\
(0.25)\end{array}$ & $\begin{array}{c}0.26 \\
(0.24)\end{array}$ & $\begin{array}{c}0.21 \\
(0.24)\end{array}$ & $\begin{array}{c}0.21 \\
(0.24)\end{array}$ \\
\hline Publicization (dummy) & $\begin{array}{c}0.30 \\
(0.27)\end{array}$ & $\begin{array}{l}-0.10 \\
(0.24)\end{array}$ & $\begin{array}{l}-0.08 \\
(0.25)\end{array}$ & $\begin{array}{l}-0.15 \\
(0.25)\end{array}$ & $\begin{array}{l}-0.20 \\
(0.24)\end{array}$ & $\begin{array}{l}-0.12 \\
(0.24)\end{array}$ & $\begin{array}{c}0.27 \\
(0.30)\end{array}$ \\
\hline Public reorganization (dummy) & $\begin{array}{c}1.05 * * * \\
(0.38)\end{array}$ & $\begin{array}{c}0.79 * * \\
(0.35)\end{array}$ & $\begin{array}{c}0.77 * * \\
(0.35)\end{array}$ & $\begin{array}{l}0.63 * \\
(0.35)\end{array}$ & $\begin{array}{c}0.53 \\
(0.34)\end{array}$ & $\begin{array}{c}0.47 \\
(0.33)\end{array}$ & $\begin{array}{c}0.87 * * \\
(0.38)\end{array}$ \\
\hline Dev. Bank (= 1 yes) & & & & & & & $\begin{array}{c}-0.82 * * \\
(0.38)\end{array}$ \\
\hline Equity & $\begin{array}{l}-0.03 \\
(0.05)\end{array}$ & $\begin{array}{c}0.07 \\
(0.04)\end{array}$ & $\begin{array}{l}0.09 * \\
(0.04)\end{array}$ & $\begin{array}{c}0.12 * * * \\
(0.04)\end{array}$ & $\begin{array}{c}0.11^{* *} \\
(0.05)\end{array}$ & $\begin{array}{c}1.79 * * * \\
(0.45)\end{array}$ & $\begin{array}{c}1.79 * * * \\
(0.45)\end{array}$ \\
\hline Equity (square) & & & & & & $\begin{array}{c}-0.06 * * * \\
(0.02)\end{array}$ & $\begin{array}{c}-0.06 * * * \\
(0.02)\end{array}$ \\
\hline Retail deposit / total funding & $\begin{array}{l}-0.01 \\
(0.00)\end{array}$ & $\begin{array}{l}0.01 * \\
(0.00)\end{array}$ & $\begin{array}{c}0.01 * * * \\
(0.00)\end{array}$ & $\begin{array}{c}0.01 \\
(0.01)\end{array}$ & $\begin{array}{c}0.01 \\
(0.01)\end{array}$ & $\begin{array}{c}0.00 \\
(0.01)\end{array}$ & $\begin{array}{l}-0.00 \\
(0.01)\end{array}$ \\
\hline Nonperforming loans / loans & $\begin{array}{c}-0.11 * * * \\
(0.01)\end{array}$ & $\begin{array}{c}-0.10 * * * \\
(0.01)\end{array}$ & $\begin{array}{c}-0.10 * * * \\
(0.01)\end{array}$ & $\begin{array}{c}-0.11 * * * \\
(0.01)\end{array}$ & $\begin{array}{c}-0.10 * * * \\
(0.01)\end{array}$ & $\begin{array}{c}-0.10 * * * \\
(0.01)\end{array}$ & $\begin{array}{c}-0.11 * * * \\
(0.01)\end{array}$ \\
\hline Equity / liability & & $\begin{array}{c}0.04^{* * *} \\
(0.00)\end{array}$ & $\begin{array}{c}0.04 * * * \\
(0.00)\end{array}$ & $\begin{array}{c}0.04 * * * \\
(0.00)\end{array}$ & $\begin{array}{c}0.04 * * * \\
(0.00)\end{array}$ & $\begin{array}{c}0.04 * * * \\
(0.00)\end{array}$ & $\begin{array}{c}0.04 * * * \\
(0.00)\end{array}$ \\
\hline Loans / retail funding & & & $\begin{array}{c}0.00 * \\
(0.00)\end{array}$ & $\begin{array}{c}0.00 \\
(0.00)\end{array}$ & $\begin{array}{c}0.00 \\
(0.00)\end{array}$ & $\begin{array}{c}0.00 \\
(0.00)\end{array}$ & $\begin{array}{c}0.00 \\
(0.00)\end{array}$ \\
\hline Macroarea effects & & & & Yes & Yes & Yes & Yes \\
\hline Time effects & & & & & Yes & Yes & Yes \\
\hline Constant & $\begin{array}{c}2.30 * * * \\
(0.86)\end{array}$ & $\begin{array}{l}-0.67 \\
(0.82)\end{array}$ & $\begin{array}{l}-1.56^{*} \\
(0.93)\end{array}$ & $\begin{array}{c}-1.82 * * \\
(0.92)\end{array}$ & $\begin{array}{l}-1.28 \\
(1.11)\end{array}$ & $\begin{array}{c}-12.50 * * * \\
(3.19)\end{array}$ & $\begin{array}{c}-12.28 * * * \\
(3.18)\end{array}$ \\
\hline Observations & 718 & 718 & 712 & 708 & 708 & 708 & 708 \\
\hline R-squared & 0.100 & 0.259 & 0.262 & 0.315 & 0.361 & 0.374 & 0.378 \\
\hline
\end{tabular}



Table 8a. Robustness: performance and ownership for different groups of countries (OLS regression: dependent variable - cost to income ratio)

\begin{tabular}{|c|c|c|c|c|c|c|c|c|c|c|c|c|c|c|c|}
\hline \multirow[b]{2}{*}{ VARIABLES } & \multicolumn{3}{|c|}{ Western EU countries } & \multicolumn{3}{|c|}{ OECD countries } & \multicolumn{3}{|c|}{ BRICST countries } & \multicolumn{3}{|c|}{ Developing countries } & \multicolumn{3}{|c|}{ Graduated developing countries } \\
\hline & $(1)$ & $(2)$ & (3) & (4) & $(5)$ & (6) & (7) & $(8)$ & (9) & $(10)$ & $(11)$ & $(12)$ & $(13)$ & $(14)$ & $(15)$ \\
\hline Own (=1 state-owned) & $\begin{array}{c}-8.19^{* *} \\
(3.34)\end{array}$ & $\begin{array}{c}-7.14 * * \\
(3.36)\end{array}$ & $\begin{array}{c}4.48 \\
(4.58)\end{array}$ & $\begin{array}{c}-15.18^{* * * *} \\
(2.78)\end{array}$ & $\begin{array}{c}-14.07 * * * \\
(2.72)\end{array}$ & $\begin{array}{l}-0.51 \\
(4.15)\end{array}$ & $\begin{array}{l}-10.88 \\
(8.86)\end{array}$ & $\begin{array}{c}-18.12^{* *} \\
(8.20)\end{array}$ & $\begin{array}{c}-3.35 \\
(10.81)\end{array}$ & $\begin{array}{l}-2.86 \\
(5.84)\end{array}$ & $\begin{array}{l}-8.88 \\
(6.89)\end{array}$ & $\begin{array}{c}1.28 \\
(9.75)\end{array}$ & $\begin{array}{c}2.83 \\
(7.52)\end{array}$ & $\begin{array}{l}-3.61 \\
(6.22)\end{array}$ & $\begin{array}{l}-6.53 \\
(6.64)\end{array}$ \\
\hline Dev. Bank (= 1 yes) & & & $\begin{array}{c}-22.37^{* * *} \\
(6.13)\end{array}$ & & & $\begin{array}{c}-21.69 * * * \\
(5.08)\end{array}$ & & & $\begin{array}{c}-25.85^{* *} \\
(12.81)\end{array}$ & & & $\begin{array}{l}-18.54 \\
(12.72)\end{array}$ & & & $\begin{array}{c}28.29 \\
(22.97)\end{array}$ \\
\hline Assets & $\begin{array}{c}-2.67 * * * \\
(0.75)\end{array}$ & $\begin{array}{c}-19.41^{* *} \\
(8.41)\end{array}$ & $\begin{array}{r}-12.34 \\
(8.46)\end{array}$ & $\begin{array}{c}-2.81 * * * \\
(0.53)\end{array}$ & $\begin{array}{c}-30.58 * * * \\
(5.43)\end{array}$ & $\begin{array}{c}-27.97 * * * \\
(5.37)\end{array}$ & $\begin{array}{c}-7.91 * * * \\
(2.02)\end{array}$ & $\begin{array}{c}-70.57^{* * *} \\
(17.16)\end{array}$ & $\begin{array}{c}-57.59^{* * *} \\
(17.86)\end{array}$ & $\begin{array}{c}-4.37^{* * *} \\
(1.06)\end{array}$ & $\begin{array}{l}-26.26 * \\
(13.85)\end{array}$ & $\begin{array}{l}-10.86 \\
(17.29)\end{array}$ & $\begin{array}{c}-6.01 * * \\
(2.44)\end{array}$ & $\begin{array}{c}-125.10^{* * *} \\
(19.73)\end{array}$ & $\begin{array}{c}-126.29 * * * \\
(19.68)\end{array}$ \\
\hline Assets (square) & & $\begin{array}{c}0.49^{* *} \\
(0.24)\end{array}$ & $\begin{array}{c}0.28 \\
(0.24)\end{array}$ & & $\begin{array}{c}0.82^{* * *} \\
(0.16)\end{array}$ & $\begin{array}{c}0.74^{* * *} \\
(0.16)\end{array}$ & & $\begin{array}{c}2.00^{* * *} \\
(0.54)\end{array}$ & $\begin{array}{c}1.59 * * * \\
(0.57)\end{array}$ & & $\begin{array}{c}0.68 \\
(0.43)\end{array}$ & $\begin{array}{c}0.20 \\
(0.53)\end{array}$ & & $\begin{array}{c}3.76^{* * * *} \\
(0.62)\end{array}$ & $\begin{array}{c}3.81 * * * \\
(0.62)\end{array}$ \\
\hline Retail deposit / total funding & $\begin{array}{c}-0.31^{* * *} \\
(0.08)\end{array}$ & $\begin{array}{c}-0.27^{* * *} \\
(0.08)\end{array}$ & $\begin{array}{c}-0.36^{* * *} \\
(0.08)\end{array}$ & $\begin{array}{c}-0.32 * * * \\
(0.06)\end{array}$ & $\begin{array}{c}-0.27 * * * \\
(0.06)\end{array}$ & $\begin{array}{c}-0.32 * * * \\
(0.06)\end{array}$ & $\begin{array}{c}0.04 \\
(0.34)\end{array}$ & $\begin{array}{c}0.06 \\
(0.30)\end{array}$ & $\begin{array}{l}-0.03 \\
(0.30)\end{array}$ & $\begin{array}{l}-0.14 \\
(0.16)\end{array}$ & $\begin{array}{l}-0.20 \\
(0.17)\end{array}$ & $\begin{array}{l}-0.22 \\
(0.16)\end{array}$ & $\begin{array}{c}0.03 \\
(0.27)\end{array}$ & $\begin{array}{c}0.07 \\
(0.22)\end{array}$ & $\begin{array}{c}0.10 \\
(0.22)\end{array}$ \\
\hline Nonperforming loans / loans & $\begin{array}{c}0.29 \\
(0.20)\end{array}$ & $\begin{array}{c}0.29 \\
(0.20)\end{array}$ & $\begin{array}{c}0.13 \\
(0.20)\end{array}$ & $\begin{array}{c}0.14 \\
(0.19)\end{array}$ & $\begin{array}{c}0.17 \\
(0.18)\end{array}$ & $\begin{array}{l}-0.02 \\
(0.19)\end{array}$ & $\begin{array}{c}2.66^{* *} \\
(1.10)\end{array}$ & $\begin{array}{c}3.49^{* * *} \\
(1.02)\end{array}$ & $\begin{array}{c}3.25 * * * \\
(0.99)\end{array}$ & $\begin{array}{c}-1.25 * * * \\
(0.30)\end{array}$ & $\begin{array}{c}-0.97 * * * \\
(0.34)\end{array}$ & $\begin{array}{c}-1.20^{* * *} \\
(0.37)\end{array}$ & $\begin{array}{c}0.18 \\
(0.43)\end{array}$ & $\begin{array}{c}0.34 \\
(0.35)\end{array}$ & $\begin{array}{c}0.35 \\
(0.35)\end{array}$ \\
\hline Equity / liability & $\begin{array}{c}-0.49^{* * *} \\
(0.10)\end{array}$ & $\begin{array}{c}-0.48^{* * *} \\
(0.10)\end{array}$ & $\begin{array}{c}-0.36^{* * *} \\
(0.10)\end{array}$ & $\begin{array}{c}-0.20^{* * *} \\
(0.05)\end{array}$ & $\begin{array}{c}-0.16 * * * \\
(0.05)\end{array}$ & $\begin{array}{c}-0.14 * * * \\
(0.05)\end{array}$ & $\begin{array}{l}-0.17 \\
(0.14)\end{array}$ & $\begin{array}{l}-0.14 \\
(0.12)\end{array}$ & $\begin{array}{l}-0.06 \\
(0.12)\end{array}$ & $\begin{array}{c}0.06 \\
(0.05)\end{array}$ & $\begin{array}{c}0.05 \\
(0.05)\end{array}$ & $\begin{array}{c}0.10 \\
(0.06)\end{array}$ & $\begin{array}{c}0.22 \\
(0.20)\end{array}$ & $\begin{array}{l}-0.15 \\
(0.18)\end{array}$ & $\begin{array}{l}-0.13 \\
(0.18)\end{array}$ \\
\hline Loans / retail funding & $\begin{array}{c}-0.10^{* * *} \\
(0.02)\end{array}$ & $\begin{array}{c}-0.09 * * * \\
(0.02)\end{array}$ & $\begin{array}{c}-0.10^{* * *} \\
(0.02)\end{array}$ & $\begin{array}{c}-0.07 * * * \\
(0.01)\end{array}$ & $\begin{array}{c}-0.06^{* * *} \\
(0.01)\end{array}$ & $\begin{array}{c}-0.06 * * * \\
(0.01)\end{array}$ & $\begin{array}{l}-0.02 \\
(0.07)\end{array}$ & $\begin{array}{l}-0.02 \\
(0.06)\end{array}$ & $\begin{array}{l}-0.04 \\
(0.06)\end{array}$ & $\begin{array}{c}-0.05^{*} \\
(0.03)\end{array}$ & $\begin{array}{c}-0.05^{*} \\
(0.03)\end{array}$ & $\begin{array}{c}-0.06 * * \\
(0.03)\end{array}$ & $\begin{array}{l}-0.17 \\
(0.11)\end{array}$ & $\begin{array}{l}-0.01 \\
(0.10)\end{array}$ & $\begin{array}{l}-0.02 \\
(0.10)\end{array}$ \\
\hline Macroarea effects & & & & Yes & Yes & Yes & Yes & Yes & Yes & Yes & Yes & Yes & Yes & Yes & Yes \\
\hline Time effects & Yes & Yes & Yes & Yes & Yes & Yes & Yes & Yes & Yes & Yes & Yes & Yes & Yes & Yes & Yes \\
\hline Constant & $\begin{array}{c}136.40 * * * \\
(20.17)\end{array}$ & $\begin{array}{c}273.38 * * * \\
(71.39)\end{array}$ & $\begin{array}{c}221.73 * * * \\
(71.33)\end{array}$ & $\begin{array}{c}134.82 * * * \\
(14.88)\end{array}$ & $\begin{array}{c}361.66^{* * *} \\
(46.50)\end{array}$ & $\begin{array}{c}345.17 * * * \\
(45.85)\end{array}$ & $\begin{array}{c}201.69 * * * \\
(47.89)\end{array}$ & $\begin{array}{c}692.40^{* * *} \\
(140.35)\end{array}$ & $\begin{array}{c}595.71 * * * \\
(144.47)\end{array}$ & $\begin{array}{c}163.15 * * * \\
(30.07)\end{array}$ & $\begin{array}{c}344.65 * * * \\
(118.31)\end{array}$ & $\begin{array}{c}218.64 \\
(145.36)\end{array}$ & $\begin{array}{c}131.65^{* *} \\
(49.97)\end{array}$ & $\begin{array}{c}1,030.59 * * * \\
(153.69)\end{array}$ & $\begin{array}{c}1,035.15 * * * \\
(153.17)\end{array}$ \\
\hline Observations & 306 & 306 & 306 & 504 & 504 & 504 & 69 & 69 & 69 & 63 & 63 & 63 & 90 & 90 & 90 \\
\hline R-squared & 0.349 & 0.358 & 0.387 & 0.257 & 0.296 & 0.322 & 0.543 & 0.638 & 0.666 & 0.641 & 0.660 & 0.675 & 0.498 & 0.671 & 0.678 \\
\hline
\end{tabular}


Table 8b. Robustness: performance and ownership for different groups of countries (OLS regression: dependent variable - ROA before taxes)

\begin{tabular}{|c|c|c|c|c|c|c|c|c|c|c|c|c|c|c|c|}
\hline \multirow[b]{2}{*}{ VARIABLES } & \multicolumn{3}{|c|}{ Western EU countries } & \multicolumn{3}{|c|}{ OECD countries } & \multicolumn{3}{|c|}{ BRICST countries } & \multicolumn{3}{|c|}{ Developing countries } & \multicolumn{3}{|c|}{ Graduated developing countries } \\
\hline & (1) & (2) & (3) & (4) & $(5)$ & (6) & (7) & $(8)$ & (9) & $(10)$ & (11) & (12) & (13) & $(14)$ & $(15)$ \\
\hline \multirow[t]{2}{*}{ Own (=1 state-owned) } & $-0.80^{* * *}$ & $-0.82 * * *$ & -0.58 & $-0.64^{* * * *}$ & $-0.61 * * *$ & -0.45 & -0.90 & -0.30 & 0.43 & -0.46 & -0.05 & -1.05 & 0.87 & 1.04 & 1.19 \\
\hline & $(0.31)$ & $(0.31)$ & $(0.41)$ & $(0.20)$ & $(0.20)$ & $(0.30)$ & $(0.70)$ & $(0.68)$ & $(0.88)$ & $(0.79)$ & $(0.92)$ & $(1.21)$ & $(0.85)$ & $(0.87)$ & $(0.93)$ \\
\hline \multirow[t]{2}{*}{ Dev. Bank (= 1 yes) } & & & -0.48 & & & -0.25 & & & -1.34 & & & 2.05 & & & -1.55 \\
\hline & & & $(0.56)$ & & & $(0.37)$ & & & $(1.03)$ & & & (1.63) & & & (3.27) \\
\hline \multirow[t]{2}{*}{ Equity } & 0.01 & -1.29 & -1.27 & $0.10^{* *}$ & $1.03 * *$ & $1.03^{* *}$ & $0.40^{* *}$ & $4.81^{* * *}$ & $5.23 * * *$ & 0.11 & 2.01 & 0.46 & 0.33 & 3.51 & 3.60 \\
\hline & $(0.07)$ & $(0.88)$ & $(0.88)$ & $(0.04)$ & $(0.40)$ & $(0.40)$ & $(0.16)$ & $(1.47)$ & $(1.50)$ & $(0.16)$ & (2.17) & (2.48) & $(0.29)$ & $(2.96)$ & (2.98) \\
\hline \multirow[t]{2}{*}{ Equity (square) } & & 0.04 & 0.04 & & $-0.03^{* *}$ & $-0.03^{* *}$ & & $-0.16^{* * *}$ & $-0.18^{* * *}$ & & -0.07 & -0.01 & & -0.12 & -0.12 \\
\hline & & $(0.03)$ & $(0.03)$ & & $(0.01)$ & $(0.01)$ & & $(0.05)$ & $(0.05)$ & & $(0.08)$ & $(0.09)$ & & $(0.11)$ & $(0.11)$ \\
\hline \multirow[t]{2}{*}{ Retail deposit / total funding } & -0.01 & -0.01 & -0.01 & 0.01 & 0.00 & 0.00 & -0.01 & -0.02 & -0.03 & $0.05^{* *}$ & $0.05 * *$ & $0.06^{* *}$ & 0.05 & 0.05 & 0.05 \\
\hline & $(0.01)$ & $(0.01)$ & $(0.01)$ & $(0.00)$ & $(0.00)$ & $(0.00)$ & $(0.03)$ & $(0.03)$ & $(0.03)$ & $(0.02)$ & $(0.02)$ & $(0.02)$ & $(0.03)$ & $(0.03)$ & $(0.03)$ \\
\hline \multirow[t]{2}{*}{ Nonperforming loans / loans } & $-0.07 * * *$ & $-0.07 * * *$ & $-0.07 * * *$ & $-0.06^{* * *}$ & $-0.06^{* * *}$ & $-0.06 * * *$ & $-0.19 * *$ & $-0.26^{* * *}$ & $-0.27 * * *$ & 0.01 & -0.01 & 0.01 & $-0.21 * * *$ & $-0.22 * * *$ & $-0.22 * * *$ \\
\hline & $(0.02)$ & $(0.02)$ & $(0.02)$ & $(0.01)$ & $(0.01)$ & $(0.01)$ & $(0.09)$ & $(0.08)$ & $(0.08)$ & $(0.04)$ & $(0.05)$ & $(0.05)$ & $(0.04)$ & $(0.04)$ & $(0.04)$ \\
\hline \multirow[t]{2}{*}{ Equity / liability } & $0.06^{* * *}$ & $0.06 * * *$ & $0.06^{* * *}$ & $0.06^{* * *}$ & $0.06^{* * *}$ & $0.06^{* * *}$ & 0.01 & 0.01 & $0.02 *$ & 0.00 & 0.01 & -0.00 & $0.05^{* *}$ & $0.05^{* *}$ & $0.05^{* *}$ \\
\hline & $(0.01)$ & $(0.01)$ & $(0.01)$ & $(0.00)$ & $(0.00)$ & $(0.00)$ & $(0.01)$ & $(0.01)$ & $(0.01)$ & $(0.01)$ & $(0.01)$ & $(0.01)$ & $(0.02)$ & $(0.02)$ & $(0.02)$ \\
\hline \multirow[t]{2}{*}{ Loans / retail funding } & 0.00 & 0.00 & 0.00 & 0.00 & 0.00 & 0.00 & -0.00 & -0.00 & -0.00 & $0.01^{* *}$ & $0.01^{* *}$ & $0.01 * * *$ & -0.00 & -0.00 & -0.00 \\
\hline & $(0.00)$ & $(0.00)$ & $(0.00)$ & $(0.00)$ & $(0.00)$ & $(0.00)$ & $(0.01)$ & $(0.00)$ & $(0.01)$ & $(0.00)$ & $(0.00)$ & $(0.00)$ & $(0.01)$ & $(0.01)$ & $(0.01)$ \\
\hline Macroarea effects & & & & Yes & Yes & Yes & Yes & Yes & Yes & Yes & Yes & Yes & Yes & Yes & Yes \\
\hline Time effects & Yes & Yes & Yes & Yes & Yes & Yes & Yes & Yes & Yes & Yes & Yes & Yes & Yes & Yes & Yes \\
\hline \multirow[t]{2}{*}{ Constant } & 0.79 & 10.02 & 9.90 & -0.85 & $-7.28 * *$ & $-7.25 * *$ & 0.29 & $-29.33^{* * *}$ & $-31.95 * * *$ & -5.69 & -19.66 & -9.69 & $-10.82^{* *}$ & -30.50 & -30.80 \\
\hline & (1.94) & (6.48) & (6.48) & $(1.02)$ & $(2.93)$ & $(2.93)$ & $(3.51)$ & $(10.34)$ & $(10.47)$ & (4.14) & (16.40) & $(18.25)$ & $(5.16)$ & (18.91) & (19.03) \\
\hline Observations & 321 & 321 & 321 & 519 & 519 & 519 & 69 & 69 & 69 & 63 & 63 & 63 & 93 & 93 & 93 \\
\hline R-squared & 0.362 & 0.367 & 0.369 & 0.550 & 0.555 & 0.555 & 0.573 & 0.638 & 0.650 & 0.299 & 0.311 & 0.335 & 0.562 & 0.569 & 0.571 \\
\hline
\end{tabular}


Table 9. Robustness: performance, type of deal and commercial vs. development banks (OLS regression: dependent variable - ROA before taxes and cost to income ratio)

\begin{tabular}{|c|c|c|c|c|c|c|c|c|}
\hline \multirow[b]{2}{*}{ VARIABLES } & \multicolumn{4}{|c|}{ ROA before taxes } & \multicolumn{4}{|c|}{ Cost to income ratio } \\
\hline & (1) & (2) & (3) & (4) & (5) & (6) & (7) & (8) \\
\hline Privatization & $\begin{array}{c}0.28 \\
(0.25)\end{array}$ & $\begin{array}{c}0.18 \\
(0.25)\end{array}$ & $\begin{array}{c}0.26 \\
(0.24)\end{array}$ & $\begin{array}{c}0.21 \\
(0.24)\end{array}$ & $\begin{array}{l}-0.99 \\
(2.62)\end{array}$ & $\begin{array}{l}-2.37 \\
(2.57)\end{array}$ & $\begin{array}{l}-2.48 \\
(2.55)\end{array}$ & $\begin{array}{l}-1.64 \\
(2.44)\end{array}$ \\
\hline Publicization*commercial & $\begin{array}{c}0.02 \\
(0.34)\end{array}$ & $\begin{array}{c}0.05 \\
(0.34)\end{array}$ & $\begin{array}{c}0.15 \\
(0.33)\end{array}$ & $\begin{array}{c}0.25 \\
(0.33)\end{array}$ & $\begin{array}{l}-6.71 * \\
(3.68)\end{array}$ & $\begin{array}{l}-2.33 \\
(3.70)\end{array}$ & $\begin{array}{l}-2.53 \\
(3.65)\end{array}$ & $\begin{array}{l}-3.84 \\
(3.49)\end{array}$ \\
\hline Publicization*development & $\begin{array}{l}-0.22 \\
(0.34)\end{array}$ & $\begin{array}{l}-0.37 \\
(0.33)\end{array}$ & $\begin{array}{l}-0.57 * \\
(0.33)\end{array}$ & $\begin{array}{l}-0.53 \\
(0.33)\end{array}$ & $\begin{array}{c}-27.19 * * * \\
(3.62)\end{array}$ & $\begin{array}{c}-28.18^{* * *} \\
(3.55)\end{array}$ & $\begin{array}{c}-25.73 * * * \\
(3.57)\end{array}$ & $\begin{array}{c}-21.56^{* * *} \\
(3.45)\end{array}$ \\
\hline PubReorg*commercial & $\begin{array}{c}1.18 * * \\
(0.48)\end{array}$ & $\begin{array}{c}1.11^{* *} \\
(0.48)\end{array}$ & $\begin{array}{c}1.03 * * \\
(0.47)\end{array}$ & $\begin{array}{l}0.92 * \\
(0.47)\end{array}$ & $\begin{array}{c}-16.48^{* * *} \\
(5.03)\end{array}$ & $\begin{array}{c}-15.02 * * * \\
(5.01)\end{array}$ & $\begin{array}{c}-14.35 * * * \\
(4.96)\end{array}$ & $\begin{array}{c}-11.40^{* *} \\
(4.75)\end{array}$ \\
\hline PubReorg*development & $\begin{array}{c}0.33 \\
(0.49)\end{array}$ & $\begin{array}{c}0.15 \\
(0.48)\end{array}$ & $\begin{array}{c}0.01 \\
(0.47)\end{array}$ & $\begin{array}{c}0.00 \\
(0.46)\end{array}$ & $\begin{array}{c}-27.09 * * * \\
(5.10)\end{array}$ & $\begin{array}{c}-27.60 * * * \\
(4.96)\end{array}$ & $\begin{array}{c}-25.98^{* * *} \\
(4.92)\end{array}$ & $\begin{array}{c}-22.36^{* * *} \\
(4.72)\end{array}$ \\
\hline Assets & $\begin{array}{l}0.09 * \\
(0.04)\end{array}$ & $\begin{array}{c}0.12 * * * \\
(0.04)\end{array}$ & $\begin{array}{c}0.11 * * \\
(0.05)\end{array}$ & $\begin{array}{c}1.79 * * * \\
(0.45)\end{array}$ & $\begin{array}{c}-3.58 * * * \\
(0.44)\end{array}$ & $\begin{array}{c}-3.27 * * * \\
(0.44)\end{array}$ & $\begin{array}{c}-3.43 * * * \\
(0.45)\end{array}$ & $\begin{array}{c}-39.19 * * * \\
(4.46)\end{array}$ \\
\hline Assets (square) & & & & $\begin{array}{c}-0.06 * * * \\
(0.02)\end{array}$ & & & & $\begin{array}{c}1.07 * * * \\
(0.13)\end{array}$ \\
\hline Retail deposit / total funding & $\begin{array}{c}0.01 * * \\
(0.00)\end{array}$ & $\begin{array}{c}0.00 \\
(0.01)\end{array}$ & $\begin{array}{c}0.00 \\
(0.01)\end{array}$ & $\begin{array}{c}-0.00 \\
(0.01)\end{array}$ & $\begin{array}{c}-0.36 * * * \\
(0.05)\end{array}$ & $\begin{array}{c}-0.36 * * * \\
(0.06)\end{array}$ & $\begin{array}{c}-0.37 * * * \\
(0.06)\end{array}$ & $\begin{array}{c}-0.27 * * * \\
(0.05)\end{array}$ \\
\hline Nonperforming loans / loans & $\begin{array}{c}-0.11 * * * \\
(0.01)\end{array}$ & $\begin{array}{c}-0.11 * * * \\
(0.01)\end{array}$ & $\begin{array}{c}-0.11 * * * \\
(0.01)\end{array}$ & $\begin{array}{c}-0.11 * * * \\
(0.01)\end{array}$ & $\begin{array}{c}0.05 \\
(0.13)\end{array}$ & $\begin{array}{c}0.07 \\
(0.14)\end{array}$ & $\begin{array}{c}0.01 \\
(0.14)\end{array}$ & $\begin{array}{c}0.08 \\
(0.14)\end{array}$ \\
\hline Equity / liability & $\begin{array}{c}0.04 * * * \\
(0.00)\end{array}$ & $\begin{array}{c}0.04 * * * \\
(0.00)\end{array}$ & $\begin{array}{c}0.04 * * * \\
(0.00)\end{array}$ & $\begin{array}{c}0.04 * * * \\
(0.00)\end{array}$ & $\begin{array}{c}-0.10 * * \\
(0.04)\end{array}$ & $\begin{array}{c}-0.08^{*} \\
(0.04)\end{array}$ & $\begin{array}{c}-0.07 * \\
(0.04)\end{array}$ & $\begin{array}{l}-0.05 \\
(0.04)\end{array}$ \\
\hline Loans / retail funding & $\begin{array}{l}0.00^{*} \\
(0.00)\end{array}$ & $\begin{array}{c}0.00 \\
(0.00)\end{array}$ & $\begin{array}{c}0.00 \\
(0.00)\end{array}$ & $\begin{array}{c}0.00 \\
(0.00)\end{array}$ & $\begin{array}{c}-0.08 * * * \\
(0.01)\end{array}$ & $\begin{array}{c}-0.08 * * * \\
(0.01)\end{array}$ & $\begin{array}{c}-0.07 * * * \\
(0.01)\end{array}$ & $\begin{array}{c}-0.05 * * * \\
(0.01)\end{array}$ \\
\hline Macroarea effects & & Yes & Yes & Yes & & Yes & Yes & Yes \\
\hline Time effects & & & Yes & Yes & & & Yes & Yes \\
\hline Constant & $\begin{array}{l}-1.47 \\
(0.94)\end{array}$ & $\begin{array}{l}-1.71 * \\
(0.93)\end{array}$ & $\begin{array}{l}-1.08 \\
(1.12)\end{array}$ & $\begin{array}{c}-12.26 * * * \\
(3.19)\end{array}$ & $\begin{array}{c}160.60 * * * \\
(10.82)\end{array}$ & $\begin{array}{c}155.57 * * * \\
(10.66)\end{array}$ & $\begin{array}{c}149.74 * * * \\
(13.30)\end{array}$ & $\begin{array}{c}433.40 * * * \\
(37.40)\end{array}$ \\
\hline Observations & 712 & 708 & 708 & 708 & 694 & 690 & 690 & 690 \\
\hline R-squared & 0.264 & 0.317 & 0.365 & 0.378 & 0.209 & 0.272 & 0.304 & 0.366 \\
\hline
\end{tabular}

